\title{
Rewriting the evolutionary history of the lichen genus Sticta (Ascomycota: Peltigeraceae subfam. Lobarioideae) in the Hawaiian islands
}

\author{
Bibiana Moncada ${ }^{1,4}$, Robert Lücking ${ }^{2,4}$ \& H. Thorsten Lumbsch ${ }^{3}$
}

\author{
Article info \\ Received: 28 Nov. 2019 \\ Revision received: 31 Mar. 2020 \\ Accepted: 31 Mar. 2020 \\ Published: 2 Jun. 2020
}

Associate Editor

Bernard Goffinet

\begin{abstract}
Hawaiian lichen species have been thought to be widespread, with low endemism. Nine species of the genus Sticta (Peltigeraceae subfamily Lobarioideae) have previously been reported for Hawaii, all supposedly cosmopolitan or Pantropical or widespread in the Paleotropics except for the putative endemic S. plumbicolor. This study is the first one employing a molecular phylogenetic approach to Hawaiian Sticta, elucidating the relationships of these conspicuous and ecologically important macrolichens. We sequenced the ITS fungal barcoding locus and used a maximum likelihood approach to reconstruct phylogenetic relationships of Hawaiian Sticta from a large dataset of more than 200 species. Thirteen species were identified among Hawaiian Sticta, four more than previously recorded. Of these, seven are new to science and putatively endemic to Hawaii. Only four previously reported species were confirmed: S. fuliginosa, S. limbata, S. plumbicolor and S. tomentosa. Together with $S$. plumbicolor and $S$. scabrosa subsp. hawaiiensis (described elsewhere), putative endemism in Hawaiian Sticta is estimated at $69 \%$. The 13 species correspond to nine or ten colonization events, predominantly from the Australasian realm. Thus, the evolutionary history of Sticta lichens in the Hawaiian archipelago is very different from what has been assumed, and matches that of other organisms in many aspects. The seven new species, all with cyanobacterial photobionts, are Sticta acyphellata, a small, stipitate Sticta with isidia and lacking cyphellae; S. antoniana, a mid-sized Sticta with abundant marginal lobules, apothecia, and a thick, grey-brown lower tomentum ending abruptly to leave a bare marginal zone; S. emmanueliana, a small, shortly stipitate Sticta forming small lobes with marginal isidia and black cilia; S. flynnii, a small, shortly stipitate Sticta with largely unbranched thallus with marginal isidia and a veined underside producing large, irregular cyphellae; S. hawaiiensis, a small Sticta with a suborbicular thallus with laminal isidia, conspicuous white cilia, and papillae on the membrane of the cyphellae; S. smithii, a small, stipitate Sticta with marginal, flattened isidia and small cyphellae; and S. waikamoi, a small to mid-sized Sticta with a much-branched thallus with slightly canaliculate lobes and marginal, dark isidia, and a thick, dark brown lower tomentum with strongly contrasting whitish cyphellae.
\end{abstract}

Key words: Hawaiian archipelago, endemism, island biogeography

\section{Introduction}

Presumably the lichen biota of the Hawaiian islands is well-known, owing to the works of Magnusson \& Zahlbruckner (1943, 1944, 1945), Magnusson (1955), Klement

\footnotetext{
${ }^{1}$ Licenciatura en Biología, Universidad Distrital Francisco José de Caldas, Cra. 4 No. 26D-54, Torre de Laboratorios, Herbario, Bogotá DC, Colombia; Research Associate, Science \& Education, The Field Museum, 1400 South Lake Shore, Chicago, IL 60605, USA

${ }^{2}$ Botanischer Garten und Botanisches Museum, Freie Universität Berlin, Königin-Luise-Straße 6-8, 14195 Berlin, Germany

${ }^{3}$ Science \& Education, The Field Museum, 1400 South Lake Shore Drive, Chicago, Illinois, 60605, USA

${ }^{4}$ Research Associate, Science \& Education, The Field Museum, 1400 South Lake Shore Drive, Chicago, Illinois, 60605, USA

* Corresponding author e-mail: r.luecking@bgbm.org
}

$(1966,1968)$ and more recently Smith and co-workers (Smith 1977, 1984, 1993, 1995, 2001, 2013; Stenroos \& Smith 1993; Smith et al. 1997). The current checklist contains 880 species in 65 genera (Smith 2013), a comparatively high number considering that only 1386 native vascular plant species are recorded for the archipelago (Imada et al. 2012). However, while $80 \%$ of the vascular plants are endemic (Wagner et al. 1999; Wagner \& Herbst 2002; Evenhuis \& Eldredge 2002), only 20-30\% of the lichen species may be unique to Hawaii (Eldredge \& Miller 1995). This estimate is in line with the assumption that lichens are generally much more widespread than vascular plants (Jørgensen 1983, 1994; Ahti 1987; 
Stevens 1991; Galloway 1991, 1994a, 2008; Ahti \& Aptroot 1992; Tibell 1994; Louwhoff 2001; Lücking \& Kalb 2001; Lücking 2003; Sipman 2006; Seaward \& Aptroot 2006; Feuerer \& Hawksworth 2007; Werth 2011). Smith's (1993) treatment of the largest family of lichenized fungi, Parmeliaceae, set the stage for viewing Hawaiian lichens as generally widespread, with few endemics (Wirth 1997; Marbach 2000; Smith 2001; Inoue 2002; Sérusiaux \& Lücking 2007). This is why the lichen biota of Hawaii has attracted considerably less interest than vascular plants have (Smith 1993). Few molecular studies have focused on Hawaiian lichens. Phylogenetic analysis showed that the presumably endemic genus Ramalinopsis, with the single species R. mannii (Follmann 1974), is nested within Ramalina, although it remains a distinctive, endemic species with a parmelioid habit (Lücking et al. 2017a; Kistenich et al. 2018). In a phylogenetic survey of the subcosmopolitan Flavoplaca citrina complex, the only available Hawaiian sample appeared on a very long branch (Vondrák et al. 2009), suggesting divergence over a long history of isolation.

Sticta is one of the best-known lichen taxa, due to its usually large, conspicuous thalli. It is easily recognized by its distinctive pores on the lower side, the cyphellae, which facilitate gas exchange (Green et al. 1981; Galloway 2007), although a small group of species centered around $S$. wrightii was shown to form a separate clade and was segregated as Dendriscosticta (Moncada et al. 2013a). Species of Sticta are characteristic of humid, coolto warm-temperate environments with high precipitation or humidity. At tropical latitudes they are most diverse and abundant in wet montane forests and alpine grasslands (páramos in the Neotropics), but are also found occasionally in lowland rain forests. Given that under favorable conditions they can accumulate large biomass and that most species are associated with nitrogen-fixing cyanobacteria, species of Sticta are significant contributors to local nitrogen input as biological fertilizers (Kelly \& Becker 1975; Becker 1980; Green et al. 1980; Green \& Lange 1991; Antoine 2004; Benner et al. 2007; Benner \& Vitousek 2012). Equally important is their role in the water cycle, since their thalli are capable of storing up to $800 \%$ of their dry weight in water and influence the microclimate of their immediate environment (Green et al. 1985; Guzmán et al. 1990; Green \& Lange 1991; Beckett 1995; Zotz et al. 1998). Species of Sticta are highly sensitive to human-induced environmental changes and pollution, and have become extinct in many areas of North America and Europe (Wirth 1995; Brodo et al. 2001; Pišút 2005; Hodkinson et al. 2014; Magain \& Sérusiaux 2015; Lendemer \& Goffinet 2016; Simon et al. 2018a; Ekman et al. 2019). This sensitivity makes them excellent indicators of environmental health, including the effects of habitat disturbance and global climate change (Scheidegger et al. 1995; Zoller et al. 1999; Radies et al. 2009).

Checklists of Hawaiian lichens (Elix \& McCarthy 1998, 2008; Smith 2013) list 11 names under Sticta, with one, $S$. crocatoides [sic] f. sandwicensis, an orthographic error for $S$. crocata f. sandwicensis, actually representing
Pseudocyphellaria sandwicensis (Moncada et al. 2014b; Lücking et al. 2017b). The remaining ten names correspond to seven species, viz. Sticta ambavillaria, S. cyphellulata, S. filix, S. fuliginosa, S. plumbicolor, S. tomentosa and $S$. weigelii, plus three varieties of the latter: $S$. weigelii var. beauvoisii, $S$. weigelii var. lutescens and $S$. weigelii var. peruviana. Sticta weigelii var. beauvoisii was recently accepted as a separate species (McDonald et al. 2003; Galloway 2006). The application of the name S. lutescens is unclear; Zahlbruckner (1925) gives S. lutescens as synonym of $S$. xanthosticta, which in turn is a synonym of Pseudocyphellaria crocata (Galloway 2001), but the lectotype of $S$. lutescens, described from Indonesia (Java), is a Sticta species. Sticta weigelii var. peruviana was described as $S$. sylvatica var. peruviana from Peru (Delise 1825 ) and subsequently considered a separate species (Nylander 1859). This taxon has been misunderstood, since the type material lacks isidia and bears abundant apothecia instead (Moncada 2012). One additional species, $S$. limbata, was identified in an ecological study (Benner \& Vitousek 2012) but has not been included in the checklist (Smith 2013). Since identifications of Hawaiian material as $S$. weigelii var. lutescens and var. peruviana are likely incorrect and may refer to specimens of $S$. weigelii s.lat., we assume that the eleven names of Sticta reported for the archipelago (excluding S. crocatoides var. sandwicensis) represent nine species, with eight of them widespread and only S. plumbicolor (Zahlbruckner 1903 , 1925) putatively endemic to Hawaii, resulting in an inferred endemism of $11 \%$.

Of the nine species reported for Hawaii, one is a green algal taxon (S. filix). The others are cyanolichens, two exclusively apotheciate ( $S$. ambavillaria, $S$. tomentosa), one sorediate ( $S$. limbata), and five isidiate or phyllidiate (S. beauvoisii, S. cyphellulata, S. fuliginosa, S. plumbicolor, $S$. weigelii). Based on published records, the eight non-endemic species presumably represent six different distribution patterns: S. filix is a chiefly Australasian species (described from New Zealand; Galloway 2007; Ranft et al. 2018); S. cyphellulata is Australasian (described from Australia) but also occurs in India and the Mascarenes (Galloway 1998, 2008; Magain \& Sérusiaux 2015; Simon et al. 2018b); S. ambavillaria (originally from Africa) has a Gondwanan distribution (Neotropics and African Paleotropics; Marcano et al. 1996; Bock et al. 2007; van den Boom et al. 2011; Eliasaro et al. 2012; Aptroot 2016; Simon et al. 2018b); S. beauvoisii (established from material from Cuba) is predominantly North American (Galloway 1995, 2006; McDonald et al. 2003); S. tomentosa (originally from Jamaica) has a Pantropical range (van den Boom et al. 2011; Moncada et al. 2014a); and $S$. fuliginosa, S. limbata (both described from Great Britain) and $S$. weigelii (described from Martinique) are subcosmopolitan (Galloway 2006; Moncada et al. 2014a; Magain \& Sérusiaux 2015). This would paint an undifferentiated, diffuse picture of the assembly of Hawaiian Sticta, apparently with stochastic colonization events from both the Eastern (Australasia) and the Western Hemisphere (North America) and almost no separate evolutionary history on the archipelago. 
A recent molecular phylogenetic revision of Sticta focusing on the northern Andes revealed that the morphological concept traditionally applied to delimit species in Sticta is ill-defined and that names such as $S$. fuliginosa and $S$. weigelii, assumed to represent cosmopolitan taxa, correspond to several distantly related lineages (Moncada et al. 2014a). Hence, we suspected that the names listed for Hawaii do not accurately reflect the diversity and taxonomic affinities of the species occurring there. This assumption is supported by two previous studies of Hawaiian lobarioid Peltigeraceae. Specifically, the seven presumably widespread species of Pseudocyphellaria s.lat. reported for Hawaii (Smith 2013) turned out to represent 12 species in three genera (Crocodia, Podostictina, Pseudocyphellaria), nine of them putatively endemic to the archipelago (Moncada et al. 2014b); for the genus Lobariella, Lücking et al. (2017c) found that instead of a single widespread species reported for Hawaii (Smith 2013), at least four taxa are present, three of them putatively endemic. In both cases, putative endemism had to be corrected from the previous $0 \%$ to $75 \%$, close to the level characterizing vascular plants.

Since Sticta was the only genus in this subfamily with at least one presumably endemic species in Hawaii (S. plumbicolor), we expected that a molecular phylogenetic revision would reveal a degree of endemism even higher than for the other two groups. To test this hypothesis we collected fresh samples of Sticta from 14 sites on the four largest islands (Kauai, Oahu, Maui, the Big Island) and extracted DNA for molecular phylogenetic analysis. Based on the results, it is evident that the evolutionary history of Sticta in the Hawaiian archipelago must indeed be rewritten.

\section{Materials and methods}

Morphological study

Herbarium material of Sticta originating from Hawaii was revised at the US National Herbarium and at the herbarium of the University of Hawaii at Manoa (HAW). We performed thin-layer chromatography to determine the chemical constituents of selected samples, following the methods outlined in Orange et al. (2010). New fresh material was collected during field work in June 2013 on the islands of Oahu, Maui and Kauai (Fig. 1), in collaboration with Clifford Smith and Philip Thomas (University of Hawaii at Manoa), Pat Bily (The Nature Conservancy, Maui) and Daniel Kaniaupio-Crozier (West Maui Soil $\&$ Water Conservation District). In addition, we received some specimens collected by C. Smith on the Big Island (Hawaii). Specimens were initially identified using keys provided by Swinscow \& Krog (1988), Joshi \& Awasthi (1982) and Galloway (1994b, 2001, 2007) for southern South America, West Africa, India and Nepal, Australia and New Zealand. For alternative taxonomic scenarios, we then compared these identifications with the older concept provided by Magnusson and Zahlbruckner (1943) and the refined concept from Moncada et al. (2014a).

\section{Molecular phylogeny}

We obtained new sequences of the nuclear ITS barcoding locus for 149 samples, including 111 from Hawaii. Molecular work was performed at the Field Museum's Pritzker Laboratory for Molecular Systematics and Evolution. DNA was extracted using the QIAGEN DNeasy Plant Mini Kit. Dilutions of 10:1 up to 10:2 were used for PCR amplifications, with the primer pairs ITS1F

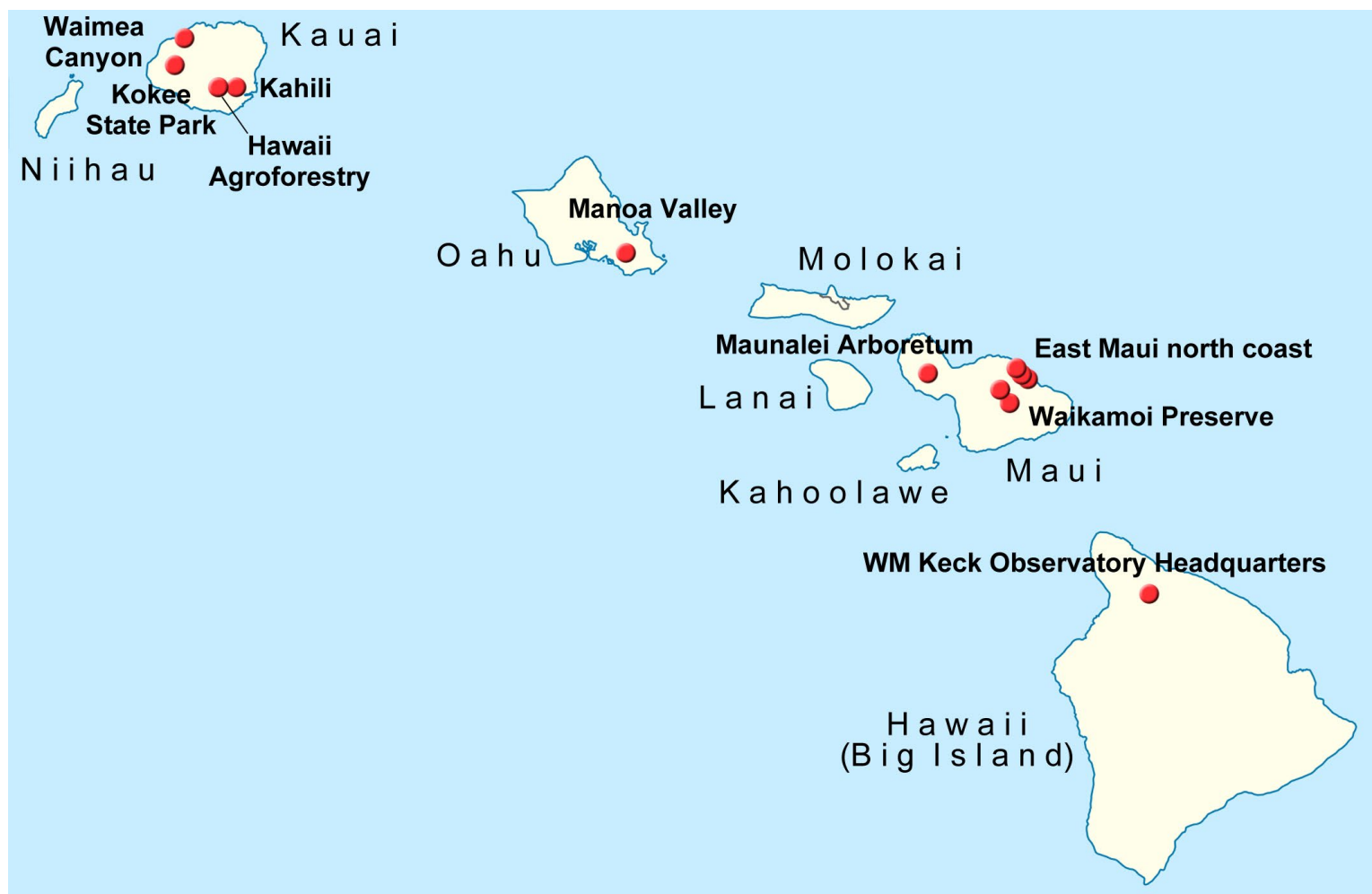

Figure 1. Hawaiian collection sites of Sticta material used for the molecular phylogenetic analysis. Based on map obtained from Wikimedia Commons [https://en.wikipedia.org/wiki/Kunia_Camp,_Hawaii\#/media/File:USA_Hawaii_location_map.svg] 
and ITS4 (Gardes \& Bruns 1993; White et al. 1990). The $25 \mu \mathrm{l}$ PCR reactions contained $2.5 \mu \mathrm{l}$ buffer, $2.5 \mu \mathrm{l}$ dNTP mix, $1 \mu \mathrm{l}$ of each primer $(10 \mu \mathrm{M}), 5 \mu \mathrm{l}$ BSA, $2 \mu \mathrm{l}$ Taq, $2 \mu \mathrm{l}$ genomic DNA extract and $9 \mu$ l distilled water. The thermal cycling parameters were set as follows: initial denaturation for $3 \mathrm{~min}$ at $95^{\circ} \mathrm{C}$, followed by 30 cycles of $1 \mathrm{~min}$ at $95^{\circ} \mathrm{C}, 1 \mathrm{~min}$ at $52^{\circ} \mathrm{C}, 1 \mathrm{~min}$ at $73{ }^{\circ} \mathrm{C}$, and final elongation for $7 \mathrm{~min}$ at $73^{\circ} \mathrm{C}$. Amplification products were mounted on $1 \%$ agarose gels stained with ethidium bromide and, after cutting of the target bands, purified using the QIAGEN QIAquick PCR Purification Kit or Nucleo Spin DNA Purification Kit (Macherey-Nagel). Fragments were sequenced using the Big Dye Terminator reaction kit (ABI PRISM, Applied Biosystems). Sequencing and PCR amplifications were performed using the same sets of primers. Cycle sequencing was executed with the following setting: 25 cycles of $95^{\circ} \mathrm{C}$ for $30 \mathrm{sec}, 48^{\circ} \mathrm{C}$ for $15 \mathrm{sec}$, $60^{\circ} \mathrm{C}$ for $4 \mathrm{~min}$. Sequenced products were precipitated with $10 \mu \mathrm{l}$ of sterile $\mathrm{dH} 2 \mathrm{O}, 2 \mu \mathrm{l}$ of $3 \mathrm{M} \mathrm{Napa}$, and $50 \mu \mathrm{l}$ of $95 \%$ EtOH, and subsequently loaded on an ABI 3100 (Applied Biosystems) automatic sequencer. Sequence fragments obtained were assembled with DNASTAR SeqMan 4.03, manually inspected and adjusted and, after quality control, submitted to GenBank (Table 1).

The obtained sequences were aligned with previously published sequences of the genus Sticta (Moncada et al. 2014a; Magain \& Sérusiaux 2015; Simon et al. 2018b; Widhelm et al. 2018; Mercado-Díaz et al. 2020; Table S1). Sequences were assembled in BIOEDIT 7.0.9 (Hall 2011) and aligned with MAFFT 7.164 using the '--add' option (Katoh \& Frith 2012; Katoh \& Standley 2013), using the ‘--auto' option and with subsequent manual inspection. The alignment was subjected to analysis of ambiguously aligned regions using the GUIDANCE webserver (Penn et al. 2010a, 2010b), but based on the results, no columns were removed, resulting in an alignment length of 684 bases (File S1). Phylogenetic analysis was performed using maximum likelihood in RAxML 8.2.0 (Stamatakis 2014) on the CIPRES Science Gateway (Miller et al. 2010), with non-parametric bootstrapping using 402 pseudoreplicates (based on an automated saturation criterion) under the GTRGAMMA model. Trees were visualized in FIGTREE 1.4.2 (Drummond \& Rambaut 2007).

\section{Time-calibrated tree}

Using a subset of 190 ingroup sequences representing different species each, a relaxed, uncorrelated lognormal molecular clock model was employed to date the evolutionary origin of the Hawaiian colonizations by Sticta lineages. BEAST 1.7.5 and 1.8.4 (Drummond \& Rambaut 2007; Drummond et al. 2012) were used for this purpose, locally and on the CIPRES Science Gateway (Miller et al. 2010), with the GTR substitution model with base frequencies estimated and Gamma and invariant sites with four Gamma categories. Speciation was estimated through a Yule process with the 'yule.birthRate' prior set to an exponential distribution with 0.7 as mean. Based on Simon et al. (2018b) and Widhelm et al. (2018), we set treeModel.rootHeight (Lobaria-Sticta split) to 45 Mya and the Sticta crown node to 25 Mya, both with a normal distribution and 5 and 3 my standard deviation, respectively. The final analysis was run for 10 million generations and every 1,000 th tree was sampled, for a total of 10,001 trees and a burn-in of 2,500 trees. The resulting log file was analysed in TRACER 1.5 and the maximum clade credibility tree was compiled using TREE ANNOTATOR 1.7.5 (Drummond \& Rambaut 2007).

\section{Results and discussion}

Phylogenetic relationships

The ITS-based phylogeny binned the Hawaiian Sticta samples into ten clades, of which two were closely related and eight were not closely related and were dispersed across the tree (Fig. 2; Fig. S1). The ten clades exhibited three different topological patterns: (1) six clades corresponded to distinct lineages representing exclusively Hawaiian specimens; (2) two clades were more widely distributed in the tropics but the Hawaiian material formed (near-)exclusive shallow subclades; and (3) two clades were more widely distributed or even subcosmopolitan and the Hawaiian specimens were dispersed within these clades, with no phylogenetic distinction from non-Hawaiian samples.

\section{Clade-based taxonomic assessment}

Morphological analysis revealed that the ten clades corresponded to 13 distinct phenotypes. The six distinct, exclusively Hawaiian lineages were each morphologically homogeneous; none of these correspond to known species and they are therefore considered undescribed taxa new to science. All are marginally isidiate and most are caulescent, but they differ in thallus size and particularly in the development and color of the lower tomentum. The early-diverging lineages 1 to 4 , below described as S. acyphellata, S. emmanueliana, S. flynnii and S. smithii, represent diminutive species which in most cases do not correspond to previously reported names (e.g., Magnusson \& Zahlbruckner 1943; Magnusson 1955), except for lineage 4, which has been reported as $S$. cyphellulata (Elix $\&$ McCarthy 1998, 2008). These taxa have apparently been overlooked in previous surveys or were mistaken for young forms of other species. For instance, of $175 \mathrm{spec}-$ imens of Sticta in HAW, only two corresponded to taxa representing these lineages; previously these had been identified as $S$. plumbicolor and $S$. weigelii, respectively. The other two lineages would correspond morphologically to either $S$. fuliginosa s.lat. (lineage 5) or S. weigelii s.lat. (lineage 6); in HAW, two specimens of lineage 5 had been identified as $S$. fuliginosa and three specimens of lineage 6 as $S$. weigelii. However, lineage 5 belongs in a complex centered around the recently reinstated $S$. ciliata and within that complex is most closely related to the recently described S. parvilobata from Puerto Rico.

The two clades containing shallow, nested subclades correspond to two more widely distributed taxa, $S$. scabrosa and S. tomentosa. Sticta scabrosa is one of the few species of the genus typically found at lower elevations 
Table 1. Genbank accession numbers of newly generated ITS sequences for Hawaiian and other representatives of Sticta used in this study.

\begin{tabular}{|c|c|c|c|c|c|c|c|}
\hline Genus & Species & Accession & Extract 1 & Extract 2 & Country & Collector & Number \\
\hline Sticta & acyphellata & MT132648 & DNA8055 & MON1186 & Hawaii Oahu & Moncada & 6923 \\
\hline Sticta & andina & MT132671 & DNA8083 & MON1214 & Hawaii Maui & Moncada & 6951 \\
\hline Sticta & andina & MT132681 & DNA8119 & MON1250 & Hawaii Maui & Moncada & 6983 \\
\hline Sticta & andina & MT132682 & DNA8120 & MON1251 & Hawaii Maui & Moncada & 6984 \\
\hline Sticta & andina & MT132693 & DNA8133 & MON1264 & Hawaii Maui & Moncada & 6997 \\
\hline Sticta & andina & MT132715 & DNA8186 & MON1317 & Hawaii Kauai & Moncada & 7047 \\
\hline Sticta & antoniana & MT132720 & DNA8192 & MON1323 & Hawaii Kauai & Moncada & $7053 a$ \\
\hline Sticta & antoniana & MT132721 & DNA8193 & MON1324 & Hawaii Kauai & Moncada & $7053 b$ \\
\hline Sticta & antoniana & MT132722 & DNA8194 & MON1325 & Hawaii Kauai & Moncada & $7053 c$ \\
\hline Sticta & antoniana & MT132733 & DNA8210 & MON1341 & Hawaii Kauai & Moncada & 7065 \\
\hline Sticta & aff. ciliata 2 & MT132628 & DNA7356 & MON0817 & Colombia & Moncada & 6135 \\
\hline Sticta & aff. ciliata 2 & MT132633 & DNA7635 & MON1011 & Colombia & Moncada & 6134 \\
\hline Sticta & aff. ciliata 2 & MT132747 & DNA 12542 & MON2542 & Colombia & Moncada & 8587 \\
\hline Sticta & aff. ciliata 3 & MT132621 & DNA7258 & MON0719 & Costa Rica & Moncada & 5713 \\
\hline Sticta & aff. ciliata 3 & MT132622 & DNA7263 & MON0724 & Costa Rica & Moncada & 5702 \\
\hline Sticta & aff. ciliata 3 & MT132623 & DNA7265 & MON0726 & Costa Rica & Moncada & 5740 \\
\hline Sticta & aff. ciliata 3 & MT132624 & DNA7268 & MON0729 & Costa Rica & Moncada & 5659 \\
\hline Sticta & aff. ciliata 3 & MT132625 & DNA7272 & MON0733 & Costa Rica & Moncada & 5775 \\
\hline Sticta & aff. ciliata 3 & MT132626 & DNA7275 & MON0736 & Costa Rica & Moncada & 5782 \\
\hline Sticta & aff. ciliata 3 & MT132634 & DNA7740 & MON1116 & Colombia & Lücking & 35839 \\
\hline Sticta & aff. ciliata 3 & MT132744 & DNA12145 & MON2145 & Colombia & Moncada & 8022 \\
\hline Sticta & cyphellulata & MT152342 & UCONN4313 & - & China & Wang & 1547066 \\
\hline Sticta & cyphellulata & MT152343 & UCONN4315 & - & China & Wang & 1547096 \\
\hline Sticta & cyphellulata & MT152344 & UCONN4317 & - & China & Wang & 1547106 \\
\hline Sticta & emmanueliana & MT132673 & DNA8087 & MON1218 & Hawaii Maui & Moncada & $6954 a$ \\
\hline Sticta & emmanueliana & MT132674 & DNA8088 & MON1219 & Hawaii Maui & Moncada & $6954 b$ \\
\hline Sticta & emmanueliana & MT132675 & DNA8089 & MON1220 & Hawaii Maui & Moncada & 6955 \\
\hline Sticta & emmanueliana & MT132726 & DNA8202 & MON1333 & Hawaii Kauai & Moncada & $7058 b$ \\
\hline Sticta & emmanueliana & MT132732 & DNA8209 & MON1340 & Hawaii Kauai & Moncada & 7064 \\
\hline Sticta & flynnii & MT132723 & DNA8196 & MON1327 & Hawaii Kauai & Moncada & $7055 \mathrm{a}$ \\
\hline Sticta & flynnii & MT132728 & DNA8205 & MON1336 & Hawaii Kauai & Moncada & 7059 \\
\hline Sticta & fuliginosa & MT132666 & DNA8077 & MON1208 & Hawaii Maui & Moncada & 6945 \\
\hline Sticta & fuliginosa & MT132677 & DNA8115 & MON1246 & Hawaii Maui & Moncada & $6979 b$ \\
\hline Sticta & fuliginosa & MT132680 & DNA8118 & MON1249 & Hawaii Maui & Moncada & 6982 \\
\hline Sticta & fuliginosa & MT132685 & DNA8124 & MON1255 & Hawaii Maui & Moncada & 6988 \\
\hline Sticta & fuliginosa & MT132687 & DNA8126 & MON1257 & Hawaii Maui & Moncada & 6990 \\
\hline Sticta & fuliginosa & MT132691 & DNA8130 & MON1261 & Hawaii Maui & Moncada & 6994 \\
\hline Sticta & fuliginosa & MT132694 & DNA8134 & MON1265 & Hawaii Maui & Moncada & 6998 \\
\hline Sticta & fuliginosa & MT132710 & DNA8159 & MON1290 & Hawaii Kauai & Moncada & 7023 \\
\hline Sticta & fuliginosa & MT132713 & DNA8182 & MON1313 & Hawaii Kauai & Moncada & 7043 \\
\hline Sticta & fuliginosa & MT132719 & DNA8191 & MON1322 & Hawaii Kauai & Moncada & 7052 \\
\hline Sticta & fuliginosa & MT132748 & DNA13512 & MON3512 & New Zealand & Lücking & 39122 \\
\hline Sticta & fuliginosa & MT132749 & DNA13514 & MON3514 & New Zealand & Lücking & 38570 \\
\hline Sticta & fuliginosa & MT132750 & DNA 13518 & MON3518 & New Zealand & Lücking & 38537 \\
\hline Sticta & fuliginosa & MT132751 & DNA13519 & MON3519 & New Zealand & Lücking & 39100 \\
\hline Sticta & fuliginosa & MT132756 & DNA13793 & MON3793 & New Zealand & Lücking & 38256 \\
\hline Sticta & fuliginosa & MT132757 & DNA 13800 & MON3800 & New Zealand & Lücking & 38418 \\
\hline Sticta & fuliginosa & MT132758 & DNA13802 & MON3802 & New Zealand & Lücking & 38433 \\
\hline Sticta & fuliginosa & MT132759 & DNA13803 & MON3803 & New Zealand & Lücking & 38454 \\
\hline Sticta & fuliginosa & MT132760 & DNA13806 & MON3806 & New Zealand & Lücking & 38913 \\
\hline Sticta & fuliginosa & MT132766 & MON5191 & - & Hawaii Big Island & Smith & s.n. \\
\hline Sticta & hawaiiensis & MT132672 & DNA8086 & MON1217 & Hawaii Maui & Moncada & 6953 \\
\hline Sticta & hawaiiensis & MT132716 & DNA8187 & MON1318 & Hawaii Kauai & Moncada & 7048 \\
\hline Sticta & limbata & MT132695 & DNA8135 & MON1266 & Hawaii Maui & Moncada & 6999 \\
\hline Sticta & limbata & MT132711 & DNA8160 & MON1291 & Hawaii Kauai & Moncada & 7024 \\
\hline Sticta & limbata & MT132752 & DNA13523 & MON3523 & New Zealand & Lücking & 39101 \\
\hline Sticta & limbata & MT132753 & DNA13525 & MON3525 & New Zealand & Lücking & $38533 a$ \\
\hline Sticta & limbata & MT132754 & DNA13531 & MON3531 & New Zealand & Lücking & 38549 \\
\hline Sticta & limbata & MT132755 & DNA13636b & MON3636b & New Zealand & Lücking & 38585 \\
\hline Sticta & limbata & MT132761 & DNA13840 & MON3840 & New Zealand & Lücking & 38424 \\
\hline
\end{tabular}


Table 1. Continued.

\begin{tabular}{|c|c|c|c|c|c|c|c|}
\hline Genus & Species & Accession & Extract 1 & Extract 2 & Country & Collector & Number \\
\hline Sticta & limbata & MT132762 & DNA13845 & MON3845 & New Zealand & Lücking & 38820 \\
\hline Sticta & marginifera & MT132630 & DNA7863 & MON0947 & India & Schumm & 18900 \\
\hline Sticta & marginifera & MT132631 & DNA7875 & MON0959 & Reunion & Schumm & 18783 \\
\hline Sticta & peltigerella & MT132627 & DNA7353 & MON0814 & Colombia & Moncada & 6359 \\
\hline Sticta & peltigerella & MT132629 & DNA7803 & MON0887 & Colombia & Lücking & 35239 \\
\hline Sticta & peltigerella & MT132763 & DNA14410 & MON4410 & Colombia & Lücking & 39523 \\
\hline Sticta & plumbicolor & MT132635 & DNA8041a & MON1172a & Hawaii Oahu & Moncada & $6910 \mathrm{a}$ \\
\hline Sticta & plumbicolor & MT132641 & DNA8049 & MON1180 & Hawaii Oahu & Moncada & 6918 \\
\hline Sticta & plumbicolor & MT132651 & DNA8057 & MON1188 & Hawaii Oahu & Moncada & 6925 \\
\hline Sticta & scabrosa subsp. hawaiiensis & MT132636 & DNA8041b & MON1172b & Hawaii Oahu & Moncada & $6910 b$ \\
\hline Sticta & scabrosa subsp. hawaiiensis & MT132637 & DNA8043 & MON1174 & Hawaii Oahu & Moncada & 6912 \\
\hline Sticta & scabrosa subsp. hawaiiensis & MT132638 & DNA8045 & MON1176 & Hawaii Oahu & Moncada & 6914 \\
\hline Sticta & scabrosa subsp. hawaiiensis & MT132639 & DNA8046 & MON1177 & Hawaii Oahu & Moncada & 6915 \\
\hline Sticta & scabrosa subsp. hawaiiensis & MT132640 & DNA8048 & MON1179 & Hawaii Oahu & Moncada & 6917 \\
\hline Sticta & scabrosa subsp. hawaiiensis & MT132642 & DNA8050 & MON1181 & Hawaii Oahu & Moncada & 6919 \\
\hline Sticta & scabrosa subsp. hawaiiensis & MT132643 & DNA8051 & MON1182 & Hawaii Oahu & Moncada & $6919 a$ \\
\hline Sticta & scabrosa subsp. hawaiiensis & MT132644 & DNA8053a & MON1184a & Hawaii Oahu & Moncada & 6921 \\
\hline Sticta & scabrosa subsp. hawaiiensis & MT132645 & DNA8053b & MON1184b & Hawaii Oahu & Moncada & 6921 \\
\hline Sticta & scabrosa subsp. hawaiiensis & MT132646 & DNA8054a & MON1185a & Hawaii Oahu & Moncada & 6922 \\
\hline Sticta & scabrosa subsp. hawaiiensis & MT132647 & DNA8054b & MON1185b & Hawaii Oahu & Moncada & 6922 \\
\hline Sticta & scabrosa subsp. hawaiiensis & MT132649 & DNA8056a & MON1187a & Hawaii Oahu & Moncada & 6924 \\
\hline Sticta & scabrosa subsp. hawaiiensis & MT132650 & DNA8056b & MON1187b & Hawaii Oahu & Moncada & 6924 \\
\hline Sticta & scabrosa subsp. hawaiiensis & MT132652 & DNA8058 & MON1189 & Hawaii Oahu & Moncada & 6926 \\
\hline Sticta & scabrosa subsp. hawaiiensis & MT132653 & DNA8059 & MON1190 & Hawaii Oahu & Moncada & 6927 \\
\hline Sticta & scabrosa subsp. hawaiiensis & MT132654 & DNA8060a & MON1191a & Hawaii Oahu & Moncada & 6928 \\
\hline Sticta & scabrosa subsp. hawaiiensis & MT132655 & DNA8060b & MON1191b & Hawaii Oahu & Moncada & 6928 \\
\hline Sticta & scabrosa subsp. hawaiiensis & MT132656 & DNA8061 & MON1192 & Hawaii Oahu & Moncada & 6929 \\
\hline Sticta & scabrosa subsp. hawaiiensis & MT132657 & DNA8063a & MON1194a & Hawaii Maui & Moncada & 6934 \\
\hline Sticta & scabrosa subsp. hawaiiensis & MT132658 & DNA8063b & MON1194b & Hawaii Maui & Moncada & 6934 \\
\hline Sticta & scabrosa subsp. hawaiiensis & MT132659 & DNA8064 & MON1195 & Hawaii Maui & Moncada & 6935 \\
\hline Sticta & scabrosa subsp. hawaiiensis & MT132660 & DNA8065 & MON1196 & Hawaii Maui & Moncada & 6938 \\
\hline Sticta & scabrosa subsp. hawaiiensis & MT132661 & DNA8066 & MON1197 & Hawaii Maui & Moncada & 6939 \\
\hline Sticta & scabrosa subsp. hawaiiensis & MT132662 & DNA8070a & MON1201a & Hawaii Maui & Moncada & 6936 \\
\hline Sticta & scabrosa subsp. hawaiiensis & MT132663 & DNA8070b & MON1201b & Hawaii Maui & Moncada & 6936 \\
\hline Sticta & scabrosa subsp. hawaiiensis & MT132664 & DNA8071a & MON1202a & Hawaii Maui & Moncada & 6937 \\
\hline Sticta & scabrosa subsp. hawaiiensis & MT132665 & DNA8071b & MON1202b & Hawaii Maui & Moncada & 6937 \\
\hline Sticta & scabrosa subsp. hawaiiensis & MT132698 & DNA8144 & MON1275 & Hawaii Maui & Moncada & 7008 \\
\hline Sticta & scabrosa subsp. hawaiiensis & MT132699 & DNA8145 & MON1276 & Hawaii Maui & Moncada & 7009 \\
\hline Sticta & scabrosa subsp. hawaiiensis & MT132700 & DNA8146 & MON1277 & Hawaii Maui & Moncada & 7010 \\
\hline Sticta & scabrosa subsp. hawaiiensis & MT132701 & DNA8147 & MON1278 & Hawaii Maui & Moncada & 7011 \\
\hline Sticta & scabrosa subsp. hawaiiensis & MT132702 & DNA8148 & MON1279 & Hawaii Maui & Moncada & 7012 \\
\hline Sticta & scabrosa subsp. hawaiiensis & MT132703 & DNA8149 & MON1280 & Hawaii Maui & Moncada & 7013 \\
\hline Sticta & scabrosa subsp. hawaiiensis & MT132704 & DNA8151 & MON1282 & Hawaii Maui & Moncada & 7015 \\
\hline Sticta & scabrosa subsp. hawaiiensis & MT132705 & DNA8153 & MON1284 & Hawaii Maui & Moncada & 7017 \\
\hline Sticta & scabrosa subsp. hawaiiensis & MT132706 & DNA8154 & MON1285 & Hawaii Kauai & Moncada & 7018 \\
\hline Sticta & scabrosa subsp. hawaiiensis & MT132707 & DNA8155 & MON1286 & Hawaii Kauai & Moncada & 7019 \\
\hline Sticta & scabrosa subsp. hawaiiensis & MT132708 & DNA8156 & MON1287 & Hawaii Kauai & Moncada & 7020 \\
\hline Sticta & scabrosa subsp. hawaiiensis & MT132709 & DNA8158 & MON1289 & Hawaii Kauai & Moncada & 7022 \\
\hline Sticta & scabrosa subsp. hawaiiensis & MT132712 & DNA8161 & MON1292 & Hawaii Kauai & Moncada & 7025 \\
\hline Sticta & scabrosa subsp. hawaiiensis & MT132718 & DNA8190 & MON1321 & Hawaii Kauai & Moncada & 7051 \\
\hline Sticta & scabrosa subsp. hawaiiensis & MT132724 & DNA8198 & MON1329 & Hawaii Kauai & Moncada & 7056 \\
\hline Sticta & scabrosa subsp. hawaiiensis & MT132725 & DNA8199 & MON1330 & Hawaii Kauai & Moncada & 7057 \\
\hline Sticta & scabrosa subsp. hawaiiensis & MT132729 & DNA8206 & MON1337 & Hawaii Kauai & Moncada & 7060 \\
\hline Sticta & scabrosa subsp. hawaiiensis & MT132731 & DNA8208 & MON1339 & Hawaii Kauai & Moncada & 7063 \\
\hline Sticta & scabrosa subsp. hawaiiensis & MT132735 & DNA8214 & MON1345 & Hawaii Kauai & Moncada & 7069 \\
\hline Sticta & scabrosa subsp. hawaiiensis & MT132736 & DNA8215 & MON1346 & Hawaii Kauai & Moncada & 7070 \\
\hline Sticta & scabrosa subsp. hawaiiensis & MT132737 & DNA8216 & MON1347 & Hawaii Kauai & Moncada & 7071 \\
\hline Sticta & scabrosa subsp. hawaiiensis & MT132738 & DNA8217 & MON1348 & Hawaii Kauai & Moncada & 7072 \\
\hline Sticta & scabrosa subsp. hawaiiensis & MT132739 & DNA8219 & MON1350 & Hawaii Kauai & Moncada & 7074 \\
\hline Sticta & scabrosa subsp. hawaiiensis & MT132740 & DNA8220 & MON1351 & Hawaii Kauai & Moncada & 7075 \\
\hline
\end{tabular}


Table 1. Continued.

\begin{tabular}{|c|c|c|c|c|c|c|c|}
\hline Genus & Species & Accession & Extract 1 & Extract 2 & Country & Collector & Number \\
\hline Sticta & scabrosa subsp. hawaiiensis & MT132741 & DNA8221 & MON1352 & Hawaii Kauai & Moncada & 7076 \\
\hline Sticta & scabrosa subsp. hawaiiensis & MT132742 & DNA8223a & MON1354a & Hawaii Kauai & Moncada & 7078 \\
\hline Sticta & scabrosa subsp. hawaiiensis & MT132743 & DNA8223b & MON1354b & Hawaii Kauai & Moncada & 7078 \\
\hline Sticta & scabrosa subsp. hawaiiensis & MT132765 & MON5190 & - & Hawaii Big Island & Smith & s.n. \\
\hline Sticta & tomentosa & MT132632 & DNA7623 & MON0999 & Colombia & Lücking & $35339 b$ \\
\hline Sticta & tomentosa & MT132667 & DNA8079a & MON1210a & Hawaii Maui & Moncada & 6947 \\
\hline Sticta & tomentosa & MT132668 & DNA8079b & MON1210b & Hawaii Maui & Moncada & 6947 \\
\hline Sticta & tomentosa & MT132669 & DNA8080 & MON1211 & Hawaii Maui & Moncada & 6948 \\
\hline Sticta & tomentosa & MT132670 & DNA8082 & MON1213 & Hawaii Maui & Moncada & 6950 \\
\hline Sticta & tomentosa & MT132676 & DNA8111 & MON1242 & Hawaii Maui & Moncada & 6977 \\
\hline Sticta & tomentosa & MT132678 & DNA8116 & MON1247 & Hawaii Maui & Moncada & 6980 \\
\hline Sticta & tomentosa & MT132679 & DNA8117 & MON1248 & Hawaii Maui & Moncada & 6981 \\
\hline Sticta & tomentosa & MT132683 & DNA8121 & MON1252 & Hawaii Maui & Moncada & 6985 \\
\hline Sticta & tomentosa & MT132684 & DNA8122 & MON1253 & Hawaii Maui & Moncada & 6986 \\
\hline Sticta & tomentosa & MT132686 & DNA8125 & MON1256 & Hawaii Maui & Moncada & 6989 \\
\hline Sticta & tomentosa & MT132688 & DNA8127 & MON1258 & Hawaii Maui & Moncada & 6991 \\
\hline Sticta & tomentosa & MT132689 & DNA8128 & MON1259 & Hawaii Maui & Moncada & 6992 \\
\hline Sticta & tomentosa & MT132690 & DNA8129 & MON1260 & Hawaii Maui & Moncada & 6993 \\
\hline Sticta & tomentosa & MT132692 & DNA8132 & MON1263 & Hawaii Maui & Moncada & 6996 \\
\hline Sticta & tomentosa & MT132697 & DNA8137 & MON1268 & Hawaii Maui & Moncada & 7001 \\
\hline Sticta & tomentosa & MT132714 & DNA8183 & MON1314 & Hawaii Kauai & Moncada & 7044 \\
\hline Sticta & tomentosa & MT132717 & DNA8189 & MON1320 & Hawaii Kauai & Moncada & 7050 \\
\hline Sticta & tomentosa & MT132727 & DNA8204 & MON1335 & Hawaii Kauai & Moncada & 7062 \\
\hline Sticta & tomentosa & MT132730 & DNA8207 & MON1338 & Hawaii Kauai & Moncada & 7061 \\
\hline Sticta & tomentosa & MT132734 & DNA8211 & MON1342 & Hawaii Kauai & Moncada & 7066 \\
\hline Sticta & tomentosa & MT132745 & DNA12175 & MON2175 & Colombia & Moncada & 8060 \\
\hline Sticta & tomentosa & MT132746 & DNA12477 & MON2477 & Colombia & Silano & P11 \\
\hline Sticta & tomentosa & MT132764 & MON4891 & - & Ecuador & Lücking & 40214 \\
\hline Sticta & waikamoi & MT132696 & DNA8136 & MON1267 & Hawaii Maui & Moncada & 7000 \\
\hline
\end{tabular}

and in more exposed situations, tolerant to disturbances, and sometimes even with a weedy aspect. The Hawaiian specimens differ consistently in two distant positions of the ITS and exhibit a tendency towards scrobiculate to foveolate (pitted) lobe tips; these are considered a subspecies (subsp. hawaiiensis; Moncada et al., unpublished). In their ecology they are similar to the nominal subspecies, which is widely distributed in the Neotropics. In Hawaii, this is by far the most frequent and widespread Sticta: 59 of the 127 sequenced specimens (46\%) and one third of the collections in HAW correspond to this taxon. By contrast, the Hawaiian material of $S$. tomentosa differs consistently from Neotropical and Paleotropical specimens only in one ITS position, with one specimen from Ecuador even corresponding to the Hawaiian haplotype; therefore, given the absence of any morphological differences, we consider this material to represent $S$. tomentosa s.str.

However, the Hawaiian material clustering phylogenetically with $S$. tomentosa contains two additional, very distinct morphotypes. One agrees with $S$. tomentosa in overall morphology, including the characteristic bluish hue, the whitish underside with thin tomentum, and the apothecia soon becoming biatorine, but features abundant laminal and marginal phyllidia and also differs in the branching pattern of the lobes, which are narrower than in typical $S$. tomentosa and often show shallow constrictions. This material matches the type of $S$. plumbicolor, which had been considered the only Hawaiian endemic species in this genus. The second morphotype strongly deviates from $S$. tomentosa in the strongly ascending, distinctly brownish (no bluish hue) lobes with rather thick and darker lower tomentum, with only the lobe tips abruptly bare of tomentum, the strongly dissected, lacinulate-lobulate lobe tips, and the apothecia remaining zeorine. This morphology corresponds perfectly to what Zahlbruckner (in Magnusson \& Zahlbruckner 1943) had identified with the name $S$. ambavillaria and is here described as $S$. antoniana (see below).

Finally, the two widespread clades with Hawaiian material nested or dispersed within correspond to three distinct morphotypes. One clade is currently being described as $S$. andina, with an $S$. weigelii morphology but unrelated to the latter (Moncada et al., unpublished). Sticta andina differs from $S$. weigelii in the much thicker lower tomentum, It is more common in high-altitude forest and shrubland, and is the most frequently encountered species in the Andean páramos. The Hawaiian material represents a single haplotype that is identical to specimens from the Northern Andes and from the Azores. The second clade represents the widespread taxa $S$. fuliginosa and $S$. limbata. Both are morphologically quite distinct, producing laminal isidia vs. marginal soredia, but based on ITS data cannot be resolved, a phenomenon that has not yet been clarified (Moncada et al. 2014a; Magain \& Sérusiaux 2015). Both taxa are present in Hawaii and correspond morphologically to specimens from other regions. 


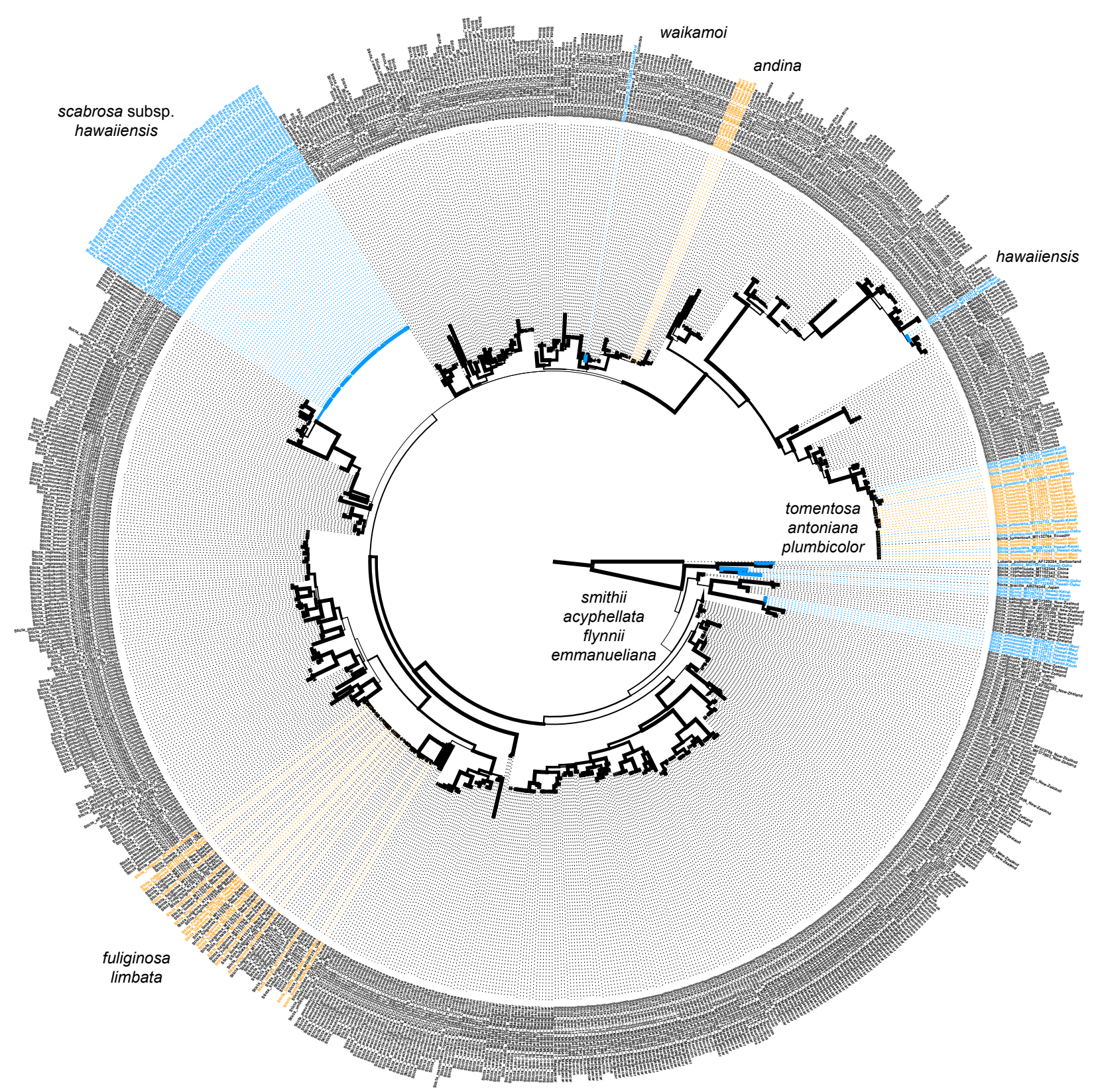

Figure 2. Best-scoring ML circle tree of Sticta based on the ITS barcoding marker. Hawaiian specimens are marked in blue (exclusive Hawaiian clades) and orange (Hawaiian specimens nested within more widely distributed taxa), and taxon names are indicated. For detailed tree with bootstrap values, see Fig. S1.

No green algal Sticta species was collected despite intensive searching. The report of S. filix by Tuckerman (1866) is likely erroneous, as already suggested by Magnusson \& Zahlbruckner (1943).

As against the nine species previously reported from Hawaii, with one presumably endemic (11\%), we found 13 taxa in the studied material, corresponding to ten phylogenetic lineages and three additional, distinct morphotypes that are not resolved with ITS. While the case of $S$. fuliginosa vs. S. limbata is a well-known phenomenon of two subcosmopolitan species (Moncada et al. 2014a; Magain \& Sérusiaux 2015), the other two cases are putative endemics in the $S$. tomentosa clade and are similar to the case reported for the putative Hawaiian endemics Pseudocyphellaria philipiana and P. pomaikaiana, each exhibiting distinct phenotypes but sharing identical ITS sequences (Moncada et al. 2014b). Since there is no phylogenetic support in the ITS fungal barcoding for these phenotypes to be recognized as species, two alternative scenarios are possible: (1) the phenotypes represent habitat-induced morphological plasticity of identical genotypes, as known for instance from photosymbiodemes; (2) the phenotypes represent distinct lineages but the ITS is not resolved to reflect this. The first scenario is not likely, since the taxa in question co-occur in the same habitats and often even side-by-side and the variation is discrete, not gradual. Support for the second scenario comes from the well-documented case of $S$. fuliginosa vs. $S$. limbata, which cannot be separated based on ITS but cannot be considered morphodemes of the same species, as they represent highly distinctive forms of vegetative reproduction (laminal isidia vs. marginal soredia). High 
morphological divergence going along with very similar genotypes has also been found in Hawaiian vascular plants, such as the Silversword alliance in the Asteraceae (Baldwin et al. 1991; Baldwin \& Sandersson 1998; Carlquist et al. 2003).

\section{Usefulness of the ITS barcoding marker for species delimitation}

The available data from Hawaiian Sticta allow further assessment of the usefulness of the fungal ITS barcoding marker for species delimitation in this genus. Multi-marker studies have previously shown that ITS phylogenies are highly congruent with those of other markers in this genus (Magain \& Sérusiaux 2015; Simon et al. 2018b; Widhelm et al. 2018), with no evidence of artifacts. This is also supported by the strong correlation between ITS-delimited species-level clades and their phenotypes (Moncada et al. 2013b, c, 2015; Magain \& Sérusiaux 2015). Thus, given the large amount of data available, there is little evidence for potential type I errors when using ITS for species delimitation in this genus. On the other hand, a few well-documented cases suggest the possibility of type II errors, that is, species not resolved by ITS alone, for example $S$. fuliginosa vs. S. limbata, S. filix vs. S. lacera, or in the present case also the three discrete morphodemes found in Hawaiian S. tomentosa s.lat. (Magain \& Sérusiaux 2015; Ranft et al. 2018; this paper).

This underlines the point that the use of ITS in revising species taxonomy in the genus Sticta can considerably improve previous treatments based on morphology alone. It should also be noted that due to the broad coverage of the current ITS phylogeny of the genus, branches appeared relatively compressed even if corresponding to substantial differences (Fig. S1). For the species recognized below, with the exception of the $S$. ciliata and $S$. tomentosa complexes, similarity (based on ITS substitutions and indels combined) to the most closely related taxa oscillated between $94.0 \%$ and $96.1 \%$ (Table 2), distinctly below the lowest fixed threshold level of $98.5 \%$ applied as default for species hypotheses (Nilsson et al. 2019). Given the critical situation of conservation of native biodiversity in island biota such as Hawaii, it also seems prudent to be more discriminant in recognizing lineages as taxa, following the concept of recognizing evolutionarily significant units (Casacci et al. 2014; Cornejo et al. 2017).

\section{Biogeography and evolutionary history}

Among the 13 taxa of Sticta now known from Hawaii, four are demonstrably widespread: S. andina, S. fuliginosa, S. limbata and S. tomentosa. The other nine are putative endemics, representing eight species and one subspecies. Notably, the only previously considered endemic species, S. plumbicolor, is phylogenetically unresolved from $S$. tomentosa based on ITS, although it displays a distinctive morphology not known from collections of $S$. tomentosa found elsewhere. Overall, this results in a degree of $69 \%$ putative endemism, comparable to the $75 \%$ found in Lobariella and in Pseudocyphellaria s.lat. but overall slightly lower (Moncada et al. 2014b; Lücking et al. 2017c). Of the nine names previously recorded for Hawaii, only four could be confirmed: S. fuliginosa, S. limbata, S. plumbicolor and S. tomentosa. Thus, between the prior taxonomy and the taxonomy to be implemented based on the results, the Sørensen overlap is only $36 \%$, which is higher than for Pseudocyphellaria s.lat. (11\%; Moncada et al. 2014b) but slightly lower than for Lobariella (40\%; Lücking et al. 2017c). Our findings thus challenge the assumption that Hawaiian lichens are widespread. In addition, lichen diversity in Hawaii appears to be substantially underestimated; if the results from the studies of lobarioid Peltigeraceae are any indication, the current number of 880 listed species represents only around $50 \%$ of the real diversity, according to which Hawaiian lichen diversity would surpass that of vascular plants (Imada et al. 2012). Overall, given the significantly increased degree of putative endemism and the substantial changes in the taxonomy of Hawaiian Sticta, the evolutionary history of this genus in the archipelago

Table 2. Quantitative analysis of ITS differences and similarity between newly recognized Hawaiian species of Sticta and their closest relatives. Length $=$ alignment length (alignment reduced to corresponding target clade); \% $=$ similarity based on number of substitutions or indels (and total) relative to alignment length. Total similarity values below $98.5 \%$ are bolded and underlined.

\begin{tabular}{|c|c|c|c|c|c|c|c|c|}
\hline Species & Species compared & Length & Substitutions & Indels & Total & $\%$ Substitutions & $\%$ Indels & $\%$ Total \\
\hline Acyphellata & flynnii + gracilis & 579 & 19 & 7 & 26 & 96.7 & 98.8 & $\underline{95.5}$ \\
\hline Emmanueliana & Caliginosa & 596 & 10 & 13 & 23 & 98.3 & 97.8 & $\underline{96.1}$ \\
\hline Emmanueliana & Marginifera & 596 & 7 & 18 & 25 & 98.8 & 97.0 & $\underline{95.8}$ \\
\hline Flynniana & Gracilis & 579 & 12 & 23 & 35 & 97.9 & 96.0 & $\underline{94.0}$ \\
\hline Hawaiiensis & ciliata s.str. & 544 & 6 & 0 & 6 & 98.9 & 100.0 & 98.9 \\
\hline Hawaiiensis & aff. ciliata 1 & 544 & 3 & 0 & 3 & 99.4 & 100.0 & 99.4 \\
\hline Hawaiiensis & aff. ciliata 2 & 544 & 5 & 0 & 5 & 99.1 & 100.0 & 99.1 \\
\hline Hawaiiensis & aff. ciliata 3 & 544 & 6 & 0 & 6 & 98.9 & 100.0 & 98.9 \\
\hline Hawaiiensis & aff. ciliata 4 & 544 & 4 & 2 & 6 & 99.3 & 99.6 & 98.9 \\
\hline Hawaiiensis & Parvilobata & 544 & 10 & 0 & 10 & 98.2 & 100.0 & 98.2 \\
\hline Hawaiiensis & aff. parvilobata & 544 & 2 & 0 & 2 & 99.6 & 100.0 & 99.6 \\
\hline Smithii & cyphellulata & 579 & 15 & 11 & 26 & 97.4 & 98.1 & $\underline{95.5}$ \\
\hline Waikamoi & aff. cordillerana & 540 & 7 & 0 & 7 & 98.7 & 100.0 & 98.7 \\
\hline Waikamoi & aff. rhizinata & 540 & 6 & 1 & 7 & 98.9 & 99.8 & 98.7 \\
\hline Waikamoi & Rhizinata & 540 & 4 & 0 & 4 & 99.3 & 100.0 & 99.3 \\
\hline
\end{tabular}


is very different from what had previously been assumed (Magnusson \& Zahlbruckner 1943; Magnusson 1955; Smith 2013).

Thus far, the lichen biota on islands has been investigated using molecular approaches in only a few cases. For the genus Sticta, the most important studies are those of Simon et al. (2018b) for Madagascar and the Mascarenes and Mercado-Díaz et al. (2020) for Puerto Rico. Particularly the first offers some basis for comparison, given that the evolutionary history of the genus Sticta in the Hawaiian archipelagos is strikingly different. The diversity of Hawaiian Sticta is the result of multiple independent colonization events, with almost no evidence of radiation or post-colonization speciation except perhaps for the closely related $S$. flynnii and $S$. smithii and the three phylogenetically unresolved species in the $S$. tomentosa complex. In contrast, in Madagascar and the Mascarenes a subclade of Sticta underwent a radiation giving rise to at least 31 species following a single colonization event (Simon et al. 2018b). Regarding other lobarioid taxa in Hawaii, the patterns in Pseudocyphellaria (Moncada et al. 2014b) are comparable to that of Hawaiian Sticta, whereas that of Lobariella reflects a potential microradiation, which, however, yielded only four species (Lücking et al. 2017c).

Under the assumption of a molecular clock, our inferences for Hawaiian Sticta suggest recent, multiple independent colonization events, mostly between 1 Mya and 2.5 Mya, and in one case (S. acyphellata) 6 Mya (Fig. 3). For comparison, the Lobariella microradiation in Hawaii was estimated, also based on ITS, at (1-)8 Mya (Lücking et al. (2017c). In contrast, the substantial Madagascar-Masquarenes radiation was dated in our analysis to between 13 Mya (crown node) and 17 Mya (stem node), between three and 15 times older than any of the inferred Hawaiian colonizations. Given that lichen fungi clearly do have a potential for insular radiations comparable to that of vascular plants (Simon et al. 2018b), the absence of such radiation in Hawaiian Sticta is therefore attributable to recent colonization of the archipelago by this genus.

While molecular clock approaches have to be considered with caution, particularly when using the length-variable ITS marker, a comparison with other time trees of the genus Sticta supports our results showing a substantial relative difference between the colonization of Hawaii and that of Madagascar and the Masquarenes. With three markers (mtSSU, nuLSU, RPB1) but with reduced ingroup sampling, Simon et al. (2018b) computed the Sticta stem node at 42 Mya, the crown node at 16 Mya, and the stem node of the Madagascar-Masquarenes radiation at 12 Mya, about 30\% younger than our ITS-based analysis. Hawaiian lineages were not included. With the Lobaria-Sticta split recovered at 46 Mya and the Sticta crown node at 27 Mya, Widhelm et al. (2018), adding two further markers (MCM7, ITS), estimated the stem and crown nodes of the Madagascar-Masquarenes radiation at 27 Mya and 15 Mya, respectively. Their crown age estimate was close to ours, whereas their stem age suggested a much older divergence of this clade. The latter is explained by a deviating underlying topology, different from other published phylogenies, with the
Madagascar-Masquarenes radiation sister to the remainder of Sticta. In the same analysis, the divergences of the included Hawaiian lineages were estimated at 5-10 Mya, about 1.5-2 times (crown node) and 2.7-5.5 times (stem node) younger than the Madagascar-Masquarenes radiation. Thus, independent of the markers employed and the underlying topology, the finding that Hawaiian colonization by the genus Sticta was much more recent than in the case of Madagascar and the Masquarenes remains.

Besides an obvious correlation between time of colonization and the potential for subsequent radiation, even in lineages that did not radiate, the phylogenetic distinctiveness of putative endemics among Hawaiian Sticta appears to be a function of time. The nine putative endemic taxa can be divided into two groups: S. acyphellata, S. emmanueliana, S. flynnii and S. smithii are taxonomically well-distinguished, whereas the other five taxa are either morphologically cryptic ( $S$. hawaiiensis, S. scabrosa subsp. hawaiiensis, S. waikamoi) or cannot be resolved based on the ITS (S. antoniana, S. plumbicolor). The first four species exhibit inferred mean divergence times of 2-6 Mya, the other five only 1-2 Mya (Fig. 3). Thus, the degree of phylogenetic and phenotypic distinctiveness of the putative endemics clearly correlates with time of isolation. In addition, the first four species all emerged from basally diverging clades in the genus Sticta, with Australasian affinities, whereas the other five taxa are placed in a large clade corresponding to a later-diverging subclade and exhibit affinities with Neotropical lineages (Fig. 2). This indicates two distinct periods of Hawaiian colonization by the genus Sticta: according to our timetree, one chiefly from Australasia in the Pliocene and another chiefly from South America in the Pleistocene. By contrast, the Madagascan-Masquarene radiation goes back to the Miocene (Simon et al. 2018b; this paper).

The notion that the absence of radiation in Hawaiian Sticta may be due to colonization events more recent than for Madagascar and the Masquarenes is consistent with findings for vascular plants. For instance, Hawaiian lobeliads in the family Campanulaceae radiated into six genera comprising 126 species, following a single colonization event about 13 Mya in the Miocene (Givnish et al. 2009), comparable to the Madagascan-Masquarene radiation in Sticta. While Madagascar is a continental island and Mauritius and Réunion are comparatively close (less than $900 \mathrm{~km}$ apart), the Hawaiian archipelago is nearly 4,000 km distant from North America and over 6,000 km from eastern Asia and Australasia (Wagner \& Funk 1995; Fleischer et al. 1998). Why were vascular plants able to colonize Hawaii much earlier than lichens in the genus Sticta? Besides the stochastic nature of dispersal history, one reason could be that epiphytic macrolichens in Peltigeraceae subfam. Lobarioidaeae thrive in more or less undisturbed forest, so their successful establishment depends on the prior formation of such ecosystems after initial colonization by vascular plants. By contrast, forest ecosystems on a continental island such as Madagascar were present long before the geological events that led to its isolation, so initial colonization by macrolichen lineages could have led to rapid radiation. 


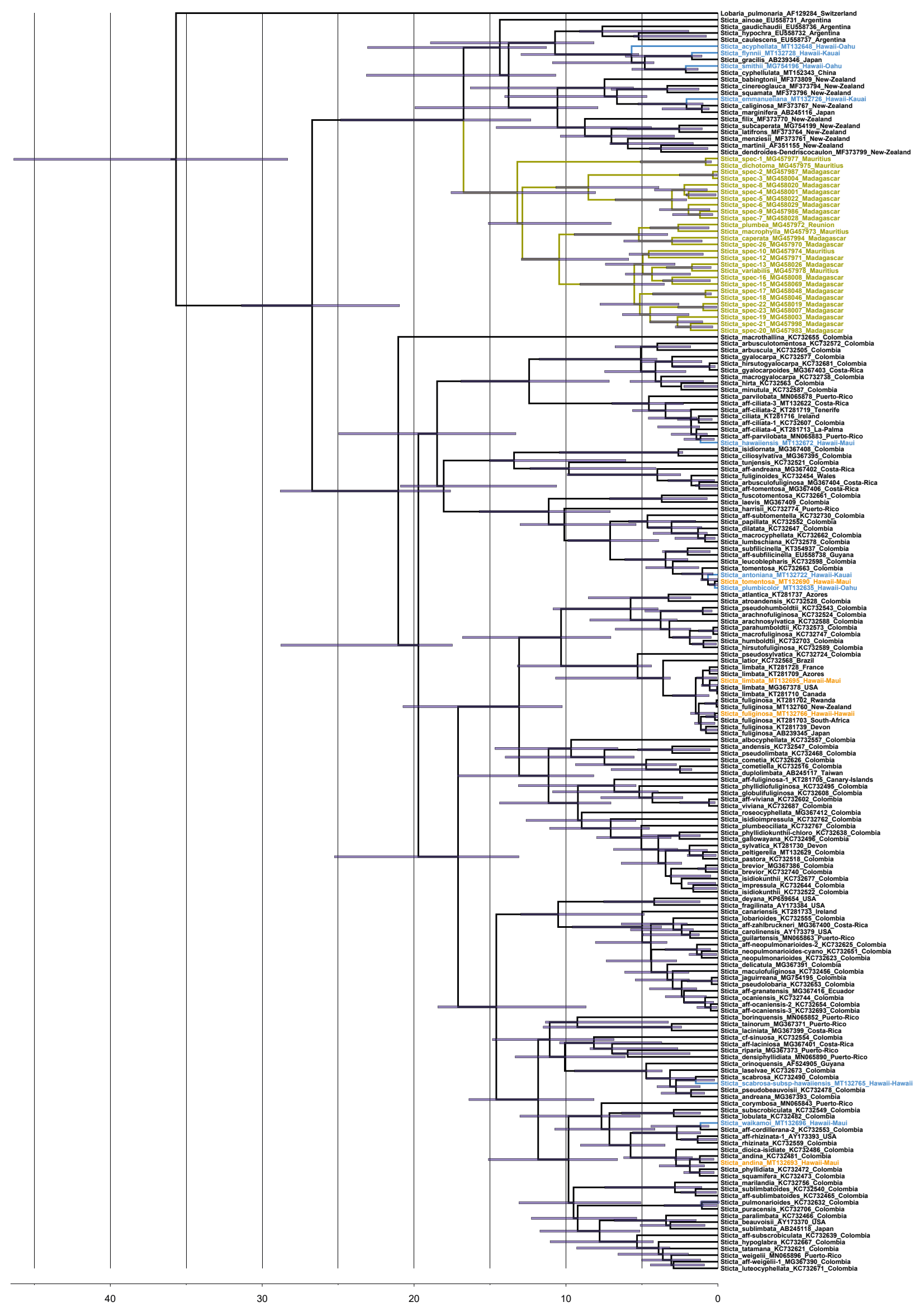

Figure 3. Chronogram of the genus Sticta based on the ITS barcoding marker, showing time of Hawaiian colonization events (in blue and orange). For comparison, the Madagascan-Masquarene radiation is highlighted in olive-green. 
The multiple colonization of the genus Sticta in Hawaii offers some statistical basis to assess the biogeographic affinities of Hawaiian lineages, as briefly outlined above. In the present case, five of the ten lineages and 13 species have Australasian affinities, including Hawaiian specimens of $S$. fuliginosa, which appear to be closest to those studied from New Zealand (Fig. S1). On the other hand, Hawaiian Sticta limbata matches specimens from Western Europe rather than from New Zealand. Three lineages and taxa appear to have New World affinities (S. andina, S. scabrosa, S. waikamoi), whereas two additional lineages corresponding to four species (S. hawaiiensis and the $S$. tomentosa complex) remain unresolved based on the geography of their closest relatives, but in our taxon sampling are also closely related to Neotropical taxa. Thus, the Hawaiian Sticta biota exhibits a slight prevalence of Australasian elements. This is comparable to the genus Pseudocyphellaria (Moncada et al. 2014b) and also agrees with the origin of the majority of vascular plant lineages. For instance, dominant forest trees of the genera Acacia (Fabaceae), Cheirodendron (Araliaceae) and Metrosideros (Myrtaceae) have Indopacific-Australasian relationships (Mueller-Dombois 1987; Wright et al. 2001; Percy et al. 2008; Brown et al. 2012; Mitchell et al. 2012), presumably due to the northern subtropical jet stream as predominant dispersal agent (Geiger et al. 2007). Biogeographic relationships with North, Central and South America have been detected in some plant groups, such as the Hawaiian Silverswords, whose closest relatives are the North American Tarweeds (Baldwin et al. 1991; Barrier et al. 2001; Carlquist et al. 2003). The only available biogeographical study of Hawaiian lichens found that most Cladoniaceae have Australasian relationships (Stenroos \& Smith 1993), whereas Neotropical affinities are apparent in the genus Lobariella (Yoshimura 1984, 1998; Yoshimura \& Arvidsson 1994; Lücking et al. 2017c). Thus, our results in the genus Sticta fit findings for other organisms and also support the notion of a complex evolutionary history of the Hawaiian biota.

Sticta offers another example of how an island biota can evolve unique phenotypes, with the first species known in the genus to entirely lack cyphellae, S. acyphellata. A comparable situation was found in the Hawaiian Phaeophyscia laciniata (Esslinger 1978), and in the presumably endemic genus Ramalinopsis (Follmann 1974) which represents a foliose species nested within the fruticose genus Ramalina (Kistenich et al. 2018). Hawaiian Lobariella revealed a novel, unique, near-fruticose phenotype in L. flynniana (Lücking et al. 2017c). The phenomenon of developing novel morphotypes on islands has been well documented for vascular plants (Fosberg 1936; Pax et al. 1997; Kidd 2005). Thus, in general it appears that Sticta and other lichen-forming fungi do not behave differently from vascular plants or other organisms in terms of their evolutionary history but match them in aspects such as endemism, diversification (related to age of origin), and the evolution of peculiar phenotypes. This has also been found for other groups of organisms such as bryophytes, which traditionally have been thought to exhibit evolutionary stasis (Medina et al. 2018).

\section{The new species}

Sticta acyphellata Moncada \& Lücking, sp. nov.

(Fig. 4A-E)

\section{MycoBank MB 835286}

Diagnosis: A diminutive, epiphytic, stipitate Sticta with a cyanobacterial photobiont, laminal to marginal isidia, and a pale underside lacking cyphellae.

Type: USA. Hawaii: Oahu, Koolau Range, Manoa Valley, $6 \mathrm{~km}$ ENE of Honolulu and $8 \mathrm{~km}$ WSW of Kaneohe, Manoa Cliffs Trail, Moleka Trailhead to Forestry Exclosure: $21^{\circ} 19^{\prime} 55^{\prime \prime} \mathrm{N}$, $157^{\circ} 48^{\prime} 43^{\prime \prime} \mathrm{E}, 410-575 \mathrm{~m}$; partially disturbed secondary forest with some exposed vegetation and some planted trees, on tree root between bryophytes; 9 June 2013, B. Moncada, R. Lücking \& C. Smith 6923 (F - holotype!; B, HAW - isotypes!).

ITS barcoding sequences: MT132648 (holotype), MG367423 (paratype).

=Sticta 'maculohyposcrobiculata' in Widhelm et al., Molec. Phylogenet. Evol. 126: 61. 2018, nom. inval.

Description. Epiphytic on bark covered with bryophyte mats; primary photobiont cyanobacterial (Nostoc). Stipe present, short. Thallus monophyllous, with several individual thalli arranged irregularly, groups of individual thalli up to $3 \mathrm{~cm}$ across; individual thalli very delicate, irregularly branched and dissected, with 7-10 branches per $5 \mathrm{~cm}$ radius; lobes spathuliform to truncate, ascending, not usually overlapping, plane to involute, margins becoming dissected, not thickened; lobe internodes $0.2-0.5 \mathrm{~cm}$ long, $0.2-0.5 \mathrm{~cm}$ broad. Upper surface even, dark bluish grey when fresh, remaining bluish grey in the herbarium, matte; surface glabrous, without papillae, without pruina, with distinct white maculae forming a reticulate pattern; marginal cilia absent. Lower surface uneven, forming distinct vein-like ridges in longitudinal direction, to finely scrobiculate-faveolate, white to cream-colored; primary tomentum present, dense but very short and inconspicuous, whitish; secondary tomentum absent. Rhizines absent. Cyphellae absent. Medulla lax, white. Upper cortex paraplectenchymatous, 20-30 $\mu \mathrm{m}$ thick, uniform, consisting of 2-3 cell layers with cells 4-8 $\mu \mathrm{m}$ diam., their walls $1-2 \mu \mathrm{m}$ thick and their lumina rounded to isodiametric, 3-6 $\mu \mathrm{m}$ diam., the innermost layer having larger cells. Photobiont layer 40-60 $\mu \mathrm{m}$ thick, its cells 5-10 $\mu \mathrm{m}$ diam. Medulla 40-60 $\mu \mathrm{m}$ thick, its hyphae 2-2.5 $\mu \mathrm{m}$ broad, nubilous due to enclosed air. Lower cortex paraplectenchymatous, 20-30 $\mu \mathrm{m}$ thick, with 1-2 cell layers; cells 5-10 $\mu \mathrm{m}$ diam., their walls $1 \mu \mathrm{m}$ thick. Hairs of lower primary tomentum $20-70 \mu \mathrm{m}$ long, of single, mostly unbranched, cylindrical, colorless hyphae. Apothecia not observed. Isidia present, abundant, marginal and laminal, becoming arbuscular, muchbranched and coralloid; arbusculae up to $0.2 \mathrm{~mm}$ long and broad, distinctly flattened, with the base of thallus color and lacking cyphellae, individual isidia $0.1-0.2 \mathrm{~mm}$ long and 0.05-0.1 broad, dark grey, shiny, flattened and slightly imbricate. Secondary chemistry: no substances detected by TLC; medulla and cyphellae K-.

Etymology. The epithet refers to the lack of cyphellae, a unique feature within the genus. 

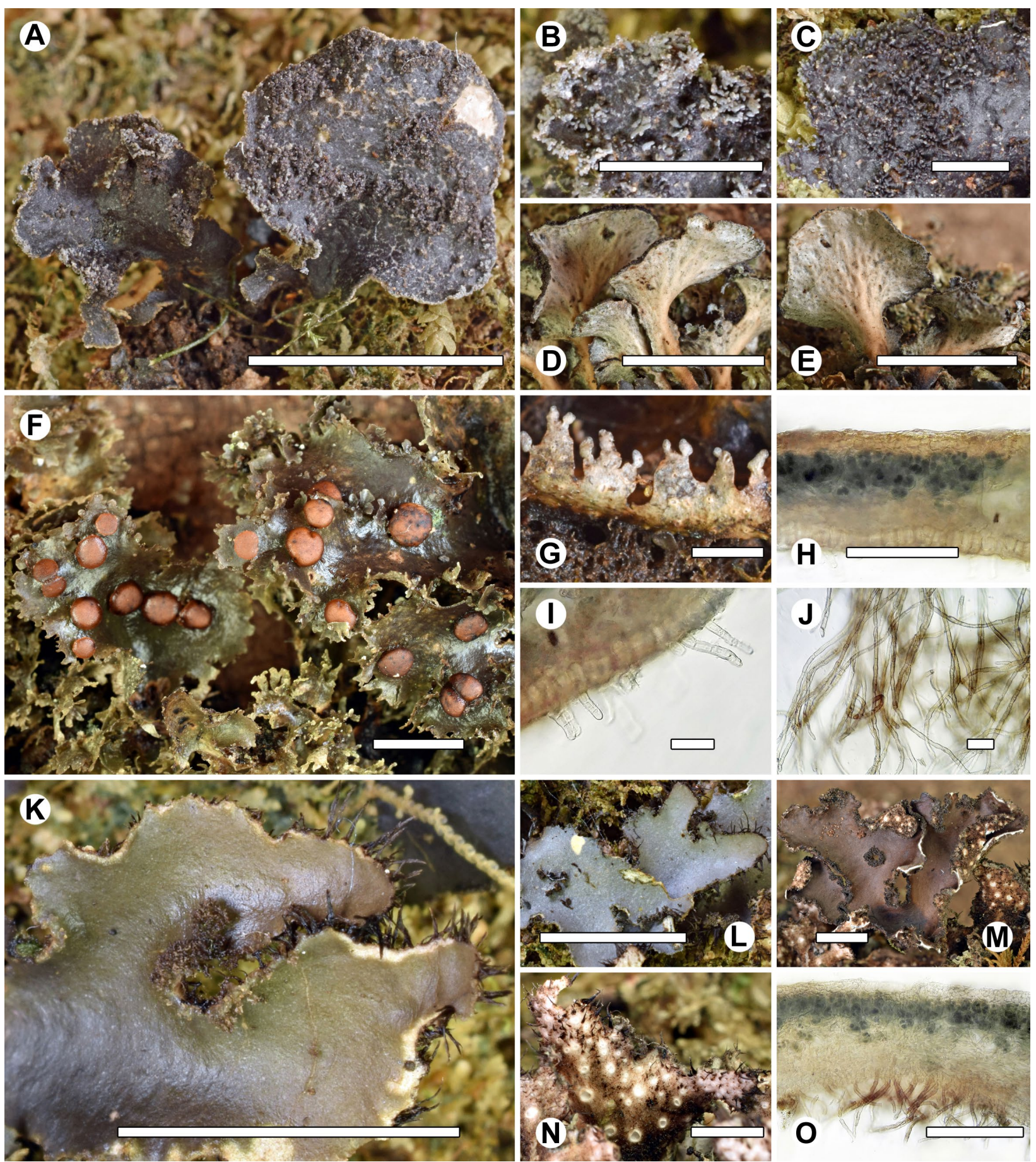

Figure 4. Morphology and anatomy of new Hawaiian Sticta species. A-E - S. acyphellata (A, thallus; B-C, upper lobe surface showing largely laminal isidia; D-E, lobe underside showing absence of cyphellae); F-J - S. antoniana (F, thallus with apothecia and marginal lobules; G, marginal lobules enlarged; H, section through thallus showing differentiated upper and lower cortex; I, section through lobe underside showing secondary tomentum hairs; J, primary tomentum hairs); $\mathrm{K}-\mathrm{O}-\mathrm{S}$. emmanueliana $(\mathrm{K}-\mathrm{M}$, thallus lobes with isidia and marginal black cilia; $\mathrm{N}$, lobe underside showing dark tomentum contrasting with whitish cyphellae and black cilia; $\mathrm{O}$, section through thallus showing primary tomentum). Scales: A, D-F, $\mathrm{K}-\mathrm{L}=5 \mathrm{~mm} ; \mathrm{B}-\mathrm{C}, \mathrm{G}, \mathrm{M}-\mathrm{N}=1 \mathrm{~mm} ; \mathrm{H}, \mathrm{O}=100 \mu \mathrm{m} ; \mathrm{I}-\mathrm{J}=10 \mu \mathrm{m}$.

Distribution and ecology. Notably, this unique species was only found in a partially disturbed secondary forest on the densely populated and strongly altered island of Oahu, where it grew epiphytic in the shaded understory near the base and on the roots of tree trunks, between bryophytes.

Notes. Sticta acyphellata is a unique species, given its diminutive size and the complete lack of cyphellae. It is the first species in the genus known with this feature. In a strictly morphological sense it would have to be classified as Lobaria s.lat., but the molecular data place it clearly within Sticta s.str. It falls near the base of the tree (Fig. 2; Fig. S1) near other cyanobacterial, stipitate species such as $S$. caulescens, S. gaudichaudii, S. hypochra, S. gracilis and S. cyphellulata, all from the Southern Hemisphere and/or Australasia (Galloway 1994b, 1998, 2001, 2007). Two other putative Hawaiian endemics, 
S. flynnii and S. smithii (see below), also belong in this clade, suggesting a previously unrecognized level of diversification in this group of species and also indicating the Southern Hemisphere and Australasia as major sources of colonization of the Hawaiian archipelago.

Phylogenetically, Sticta acyphellata is unsupported sister to a clade formed by $S$. gracilis (Japan) and S. flynnii (Hawaii). The two clades differ substantially in 19 substitutions and seven indels in the ITS (Table 2; Fig. S1).

Additional specimen examined. USA. Hawaii: Oahu, Koolau Range, Manoa Valley, $6 \mathrm{~km}$ ENE of Honolulu and $8 \mathrm{~km}$ WSW of Kaneohe, Manoa Cliffs Trail, Moleka Trailhead to Forestry Exclosure: $21^{\circ} 19^{\prime} 55^{\prime \prime} \mathrm{N}, 157^{\circ} 48^{\prime} 43^{\prime \prime} \mathrm{E}, 410-575 \mathrm{~m}$; partially disturbed secondary forest with some exposed vegetation and some planted trees, on tree base between bryophytes; 9 June 2013, B. Moncada, R. Lücking \& C. Smith 6920 (B, F - paratypes!).

\section{Sticta antoniana Moncada \& Lücking, sp. nov.}

(Fig. 4F-J)

\section{MycoBank MB 835287}

Diagnosis: A mid-sized, epiphytic Sticta with a cyanobacterial photobiont, with much-branched, brownish grey thallus forming ascending lobes featuring abundant marginal lobules, frequent apothecia, and a thick, grey-brown lower tomentum ending abruptly to leave a bare, marginal, whitish zone; closely related to $S$. tomentosa but differing from the latter in color, the marginally lobulate lobes and the thick, abruptly ending lower tomentum.

Type: USA, Hawaii: Kauai, West Kauai, western slopes of Mount Wai'ale'ale, Koke'e State Park, 20 km ENE of Waimea and $35 \mathrm{~km} \mathrm{NW}$ of Lihue, at end of Kokee Road, Pihea Trail; $22^{\circ} 08^{\prime} 51^{\prime \prime} \mathrm{N}, 159^{\circ} 37^{\prime} 53^{\prime \prime} \mathrm{E}, 1250-1350 \mathrm{~m}$; mostly undisturbed montane mesic forest, on tree bark; 15 June 2013, B. Moncada, R. Lücking \& T. Flynn 7053 (F - holotype!; B, HAW - isotypes!).

ITS barcoding sequences: MT132720, MT132721, MT132722 (holo- and isotypes), MG367433, MT132733 (paratypes).

= Sticta 'tomentosa/hawaiiensis 3' in Widhelm et al., Molec. Phylogenet. Evol. 126: 62. 2018, nom. inval.

Description. Epiphytic on bark; primary photobiont cyanobacterial (Nostoc). Stipe absent. Thallus monophyllous, irregularly orbicular, up to $10 \mathrm{~cm}$ across, frequently anisotomously branched, with $7-15$ branches per $5 \mathrm{~cm}$ radius; lobes flabellate to truncate, ascending, not usually overlapping, margins much dissected into elongate lobules, not thickened; lobe internodes $0.2-0.5 \mathrm{~cm}$ long, $0.2-0.5 \mathrm{~cm}$ broad. Upper surface even, olive-green when fresh, brownish grey in the herbarium, slightly shiny; surface glabrous, without papillae, without pruina, without or with scattered, indistinct maculae; cilia absent. Lower surface slightly uneven, whitish; primary tomentum thick and dense, forming light grey-brown, arachnoid tufts of fasciculate hyphae except for $2-5 \mathrm{~mm}$ broad marginal zone abruptly bare of tomentum; secondary tomentum absent. Rhizines absent. Cyphellae rather dense, 21-60 per $\mathrm{cm}^{2}$, rounded, plane, immersed, white; pore $0.1-$ $0.3 \mathrm{~mm}$ diam. Medulla lax, white. Upper cortex paraplectenchymatous, $20-30 \mu \mathrm{m}$ thick, uniform, consisting of 2-3 layers, cells 5-8 $\mu \mathrm{m}$ diam., their walls $1-2 \mu \mathrm{m}$ thick and their lumina rounded to isodiametric, $3-6 \mu \mathrm{m}$ diam., yellowish. Photobiont layer $30-50 \mu \mathrm{m}$ thick, its cells $5-10 \mu \mathrm{m}$ diam. Medulla $30-50 \mu \mathrm{m}$ thick, its hyphae 2-2.5 $\mu \mathrm{m}$ broad, nubilous due to enclosed air. Lower cortex paraplectenchymatous, $20-30 \mu \mathrm{m}$ thick, with single cell layer; cells 7-12 $\mu \mathrm{m}$ diam., more or less palisadic (higher than broad), their walls $1-1.5 \mu \mathrm{m}$ thick, yellowish. Hairs of lower primary tomentum $500-1500 \mu \mathrm{m}$ long, formed by densely entangled, mostly unbranched, pale brown, cylindrical hyphae with free apices; hairs of lower secondary tomentum scattered, 20-30 $\mu \mathrm{m}$ long, of single, unbranched, cylindrical, colorless hyphae. Cells of basal membrane of cyphellae irregularly bulging but lacking distinct papillae. Apothecia common, laminal, sessile, at first zeorine with hairy margins but mature apothecia biatorine, with remnants of thallus layer basally and with scattered marginal hairs; disc rather dark reddish brown; margin crenulate, cream-colored to pale orange. Ascospores oblong-fusiform, 3-septate, 40-50 $\times 6-7 \mu \mathrm{m}$. Marginal lobules abundant, much-branched, $1-3(-5) \mathrm{mm}$ long and $0.5-1 \mathrm{~mm}$ broad, of the same color as thallus. Secondary chemistry: no substances detected by TLC; medulla and cyphellae $\mathrm{K}-$.

Etymology. The species name honors the legacy of Anton Zahlbruckner, for his invaluable contributions to lichenology, including Hawaiian lichens, a work he did not see completed before his death (Magnusson \& Zahlbruckner 1943), and who first noted the distinctiveness of this species.

Distribution and ecology. Sticta antoniana was found on the islands of Maui and Kauai, in both cases in more or less undisturbed montane forest at mid elevations (between 1000 and $1500 \mathrm{~m}$ ), on shaded tree bark.

Notes. This new species is here formally introduced, although the molecular data of the ITS fungal barcoding locus do not provide sufficient resolution to distinguish it phylogenetically from Sticta tomentosa (Fig. 2; Fig. S1). Yet, morphologically, it is set apart from the latter by the brownish (not bluish) grey thallus with numerous marginal lobules and by the thick, abruptly ending lower tomentum; $S$. tomentosa only rarely produces adventive lobules and the lower tomentum is uniformly pale and becomes gradually thinner towards margins. Zahlbruckner (in Magnusson \& Zahlbruckner 1943: 90) was the first to notice the features of this taxon, the material at that time being included under the name S. ambavillaria: 'Die Exemplare aus Kauai zeichnen sich durch stark gegliederte Lappen des Lagers aus und stimmen darum weniger wit der Figur in Delise, Hist. Lich. ...'. Sticta ambavillaria does not seem to occur in Hawaii; at least we have not found any authentic material. That species produces rather broad, uneven lobes lacking marginal lobules.

Additional specimen examined: U.S.A. Hawaii: Maui, East Maui, Haleakalā Volcano, Lower Waikamoi Preserve (The Nature Conservancy), $5 \mathrm{~km}$ SE of Pulakani and $18 \mathrm{~km} \mathrm{SE}$ of Kahului, lower access trail to preserve off Olinda Road; $20^{\circ} 48^{\prime} 23^{\prime \prime} \mathrm{N}, 156^{\circ} 15^{\prime} 19^{\prime \prime} \mathrm{E}, 1200-1300 \mathrm{~m}$; 
disturbed primary forest dominated by Acacia koa and Campanulaceae, with invasive Hedychium gardnerianum in lower portions; on tree bark at base in shaded conditions, 11 June 2013, B. Moncada, R. Lücking \& P. Bily 6947 (B, F, HAW - paratypes!), 6948 (B, F - paratypes!). Kauai, West Kauai, western slopes of Mount Wai'ale'ale, Koke'e State Park, $20 \mathrm{~km}$ ENE of Waimea and $35 \mathrm{~km}$ NW of Lihue, at end of Kokee Road, Pihea Trail; $22^{\circ} 08^{\prime} 51^{\prime \prime} \mathrm{N}$, $159^{\circ} 37^{\prime} 53^{\prime \prime} \mathrm{E}, 1250-1350 \mathrm{~m}$; mostly undisturbed montane mesic forest, on tree bark; 15 June 2013, B. Moncada, R. Lücking \& T. Flynn 7045a (F - paratype!); ibid., on tree bark of Cheirodendron sp., 15 June 2013, B. Moncada, R. Lücking \& T. Flynn 7065 (F - paratype!).

Sticta emmanueliana Moncada, Lücking \& Lumbsch, sp. nov.

(Fig. 4K-O)

\section{MycoBank MB 835288}

Diagnosis: A small, epiphytic, shortly stipitate Sticta with a cyanobacterial photobiont, with branched, olive-brown to brownish grey thallus forming small lobes with marginal, arbuscular-coralloid isidia and black cilia.

Type: USA, Hawaii: Kauai, West Kauai, western slopes of Mount Wai'ale'ale, Koke'e State Park, 20 km ENE of Waimea and $35 \mathrm{~km} \mathrm{NW}$ of Lihue, at end of Kokee Road, Pihea Trail; $22^{\circ} 08^{\prime} 51^{\prime \prime} \mathrm{N}, 159^{\circ} 37^{\prime} 53^{\prime \prime} \mathrm{E}, 1250-1350 \mathrm{~m}$; mostly undisturbed montane mesic forest, on tree bark; 15 June 2013, B. Moncada, R. Lücking \& T. Flynn 7058 (F - holotype!; B, HAW - isotypes!).

ITS barcoding sequences: MT132726 (holotype), MG367425, MT132673, MT132674, MT132675, MT132732 (paratypes).

= Sticta 'isidiopedunculata' in Widhelm et al., Molec. Phylogenet. Evol. 126: 61. 2018, nom. inval.

Description. Epiphytic on bark covered with bryophyte mats or more rarely on branches; primary photobiont cyanobacterial (Nostoc). Stipe present, short and broad. Thallus mono- to polyphyllous, with one to few individual thalli arranged irregularly, groups of individual thalli up to $5 \mathrm{~cm}$ across; individual thalli delicate, irregularly branched, with $2-4$ branches per $5 \mathrm{~cm}$ radius; lobes irregularly elongate to tapering or truncate, horizontal to ascending, not usually overlapping, plane to slightly involute, margins not thickened; lobe internodes 3-5 mm long, 1-3 mm broad. Upper surface even, olive-brown to dark brown when fresh, brownish grey in the herbarium, matte; surface glabrous, without papillae, without pruina, with scattered white maculae; marginal cilia present, formed by isolated, submarginal tufts of primary tomentum that become visible beyond margins, conspicuous particularly in younger lobes, becoming evanescent in old lobes, (brown-)black, 0.1-0.4 mm long. Lower surface uneven, mostly dark brown (particularly towards center) but marginally becoming white to cream-colored, either in streaks or entirely so; primary tomentum present but becoming thin towards margins except for the (sub-marginal) cilia, otherwise forming loosely to densely arranged brown tufts of fasciculate hyphae, much shorter and lighter than the (sub-)marginal cilia; secondary tomentum developed up to margins, thin, pubescent, whitish to light brownish. Rhizines absent. Cyphellae dense, 41-80 per $\mathrm{cm}^{2}$, rounded, immersed-erumpent, white, appearing pruinose, with cream-colored to light brown margin bare of tomentum; pore $0.1-0.2 \mathrm{~mm}$ diam. towards margins, $0.2-0.5 \mathrm{~mm}$ diam. towards center. Medulla lax, white. Upper cortex paraplectenchymatous, $10-15 \mu \mathrm{m}$ thick, uniform, consisting of 2-3 cell layers with cells $4-8 \mu \mathrm{m}$ diam., their walls $1-2 \mu \mathrm{m}$ thick and their lumina rounded to isodiametric, 3-6 $\mu \mathrm{m}$ diam. Photobiont layer 20-30 $\mu \mathrm{m}$ thick, its cells $5-10 \mu \mathrm{m}$ diam. Medulla $30-50 \mu \mathrm{m}$ thick, its hyphae 2-2.5 $\mu \mathrm{m}$ broad, nubilous due to enclosed air. Lower cortex paraplectenchymatous, 15-25 $\mu \mathrm{m}$ thick, with 2-3 cell layers; cells 5-10 $\mu \mathrm{m}$ diam., their walls $1-2 \mu \mathrm{m}$ thick. Hairs of lower primary tomentum 100 $200 \mu \mathrm{m}$ long, in fascicles of 10-20, mostly unbranched but loosely agglutinate, cylindrical hyphae with free apices, usually brownish; hairs of lower secondary tomentum 25-100 $\mu \mathrm{m}$ long, of single, mostly unbranched, cylindrical hyphae with free apices, pale brown. Cells of basal membrane of cyphellae irregularly bulging but without distinct papillae. Apothecia not observed. Isidia present, abundant, predominantly marginal, arbuscular, much-branched and becoming coralloid; arbusculae up to $0.5 \mathrm{~mm}$ long and broad, with the base of thallus color and lacking cyphellae, individual isidia $0.1-0.3 \mathrm{~mm}$ long and $0.05-0.1 \mathrm{~mm}$ broad; grey-brown, shiny, cylindrical. Secondary chemistry: no substances detected by TLC; medulla and cyphellae $\mathrm{K}$ - to $\mathrm{K}+$ pale yellow.

Etymology. We are delighted to dedicate this new species to our colleague and friend, Emmanuël Sérusiaux, on the occasion of his official retirement from formal duties but certainly not from lichenology. Emmanuël has made numerous invaluable contributions to lichenology in almost all taxonomic groups and geographic areas, but especially in tropical lichenology. We congratulate him on his great achievements!

Distribution and ecology. Sticta emmanueliana appears to be similar in ecology to $S$. antoniana, having been found at exactly the same localities on the islands of Maui and Kauai, in both cases in more or less undisturbed montane forest at mid elevations (between 1000 and $1500 \mathrm{~m}$ ), on shaded tree bark. An older collection is also from Maui, at higher elevation (1800 m).

Notes. Based on the marginal isidia and black cilia, this new species would perhaps be identified with the name Sticta cometiella, originally described from Mexico. However, the latter, apparently a strictly Neotropical taxon, is entirely unrelated, clustering in a different clade in another portion of the tree, and differs also in the frequently laminal isidia (Moncada 2012; Moncada et al. 2014a). Another similar stipitate species with marginal isidia and cilia is S. duplolimbata, which has an Australasian distribution (Galloway 1998). However, the latter is also unrelated to $S$. emmanueliana but in turn sister to $S$. cometiella (Fig. S1). This is another example of superficially similar phenotypes that evolved independently in different lineages of the genus, as already shown for $S$. fuliginosa and S. limbata (Moncada et al. 2014a; Magain \& Sérusiaux 2015). 
Phylogenetically close to $S$. emmanueliana are the Paleotropical S. marginifera and S. caliginosa from New Zealand; both are stipitate and marginally isidiate but lack cilia (Galloway 1998, 2007). Sticta emmanueliana is strongly supported sister to a clade formed by the latter two species (Fig. 2; Fig. S1), forming a basal, paraphyletic grade. It differs from $S$. caliginosa (New Zealand) substantially in ten substitutions and 13 indels and from $S$. marginifera (Paleotropics) in seven substitutions and 18 indels in the ITS (Table 2).

Additional specimen examined. USA. Hawaii: Maui, East Maui, Haleakalā Volcano, Lower Waikamoi Preserve (The Nature Conservancy), $5 \mathrm{~km}$ SE of Pulakani and $18 \mathrm{~km} \mathrm{SE}$ of Kahului, lower access trail to preserve off Olinda Road; $20^{\circ} 48^{\prime} 23^{\prime \prime} \mathrm{N}, 156^{\circ} 15^{\prime} 19^{\prime \prime} \mathrm{E}, 1200-1300 \mathrm{~m}$; disturbed primary forest dominated by Acacia koa and Campanulaceae, with invasive Hedychium gardnerianum in lower portions; on tree bark, 11 June 2013, B. Moncada, R. Lücking \& P. Bily 6949 (F - paratype!), 6954 (B, F, HAW - paratypes!), 6955 (F paratype!). Maui, East Maui, Makawao Forest Reserve, below Pu'u Nianiau; 1800 m; over moss on Myrsine trunk, 15 June 1975, C. W. Smith 1922 (HAW). Kauai, West Kauai, western slopes of Mount Wai'ale'ale, Koke'e State Park, 20 km ENE of Waimea and $35 \mathrm{~km}$ NW of Lihue, at end of Kokee Road, Pihea Trail; $22^{\circ} 08^{\prime} 51^{\prime \prime} \mathrm{N}, 159^{\circ} 37^{\prime} 53^{\prime \prime} \mathrm{E}, 1250-1350 \mathrm{~m}$; mostly undisturbed montane mesic forest, on tree bark; 15 June 2013, B. Moncada, R. Lücking \& T. Flynn 7045a (F - paratype!); ibid., on tree bark, 15 June 2013, B. Moncada, R. Lücking \& T. Flynn 7064 (F - paratype!).

Sticta flynnii Moncada \& Lücking, sp. nov. (Fig. 5A-E)

\section{MycoBank MB 835289}

Diagnosis: A small, epiphytic, shortly stipitate Sticta with a cyanobacterial photobiont, with largely unbranched, olive-green to bluish grey thallus with marginal, arbuscular-coralloid isidia, with pale, shallowly veined underside producing rather large, irregular cyphellae.

Type: USA, Hawaii: Kauai, West Kauai, western slopes of Mount Wai'ale'ale, Koke'e State Park, 20 km ENE of Waimea and $35 \mathrm{~km} \mathrm{NW}$ of Lihue, at end of Kokee Road, Pihea Trail; $22^{\circ} 08^{\prime} 51^{\prime \prime} \mathrm{N}, 159^{\circ} 37^{\prime} 53^{\prime \prime} \mathrm{E}, 1250-1350 \mathrm{~m}$; mostly undisturbed montane mesic forest, on tree bark; 15 June 2013, B. Moncada, R. Lücking \& T. Flynn 7055 (F - holotype!).

ITS barcoding sequences: MT132723-MG367434 (holotype), MT132728 (paratype).

= Sticta 'albohypoarbuscula' in Widhelm et al., Molec. Phylogenet. Evol. 126: 60. 2018, nom. inval.

Description. Epiphytic on bark covered with bryophyte mats; primary photobiont cyanobacterial (Nostoc). Stipe present, short and broad. Thallus mono- to polyphyllous, with one to few individual thalli arranged irregularly, groups of individual thalli up to $5 \mathrm{~cm}$ across; individual thalli delicate, unbranched to sparsely branched, with 0-1 branches per $5 \mathrm{~cm}$ radius but becoming apically dissected; lobes suborbicular to reniform or truncate, ascending, not usually overlapping, plane to involute, margins becoming coarsely dissected, not thickened; lobe internodes $0.5-1 \mathrm{~cm}$ long, $1-3 \mathrm{~cm}$ broad. Upper surface even, olivegreen when fresh, bluish grey in the herbarium, matte; surface glabrous, without or with scattered papillae, without pruina, with scattered white maculae; marginal cilia absent. Lower surface uneven, forming shallow, vein-like ridges. in longitudinal direction, white to creamcolored; primary tomentum absent; secondary tomentum developed up to margins, thin, pubescent, white. Rhizines absent. Cyphellae scattered, 1-20 per $\mathrm{cm}^{2}$ towards thallus center and 21-40 per $\mathrm{cm}^{2}$ towards margin, rounded to irregular or becoming angular, plane, immersed, white, appearing pruinose; pore $0.5-1 \mathrm{~mm}$ diam. towards margins, 1-3 mm across towards center. Medulla lax, white. Upper cortex paraplectenchymatous, 20-30 $\mu \mathrm{m}$ thick, uniform, consisting of 2-3 cell layers with cells 5-10 $\mu \mathrm{m}$ diam., their walls $\sim 1 \mu \mathrm{m}$ thick and their lumina isodiametric, 4-9 $\mu \mathrm{m}$ diam. Photobiont layer 30-70 $\mu \mathrm{m}$ thick, its cells $5-10 \mu \mathrm{m}$ diam. Medulla $30-50 \mu \mathrm{m}$ thick, its hyphae 2-2.5 $\mu \mathrm{m}$ broad, nubilous. Lower cortex paraplectenchymatous, 20-25 $\mu \mathrm{m}$ thick, with 1-2 cell layers; cells 5-10 $\mu \mathrm{m}$ diam., their walls $1-2 \mu \mathrm{m}$ thick. Hairs of lower secondary tomentum 20-50 $\mu \mathrm{m}$ long, of single, mostly unbranched, cylindrical hyphae with free apices. Cells of basal membrane of cyphellae irregularly bulging but without distinct papillae. Apothecia not observed. Isidia present, abundant, mostly marginal but in part also laminal, arbuscular, much-branched and becoming coralloid; arbusculae up to $2 \mathrm{~mm}$ long and broad, with the base of thallus color and lacking cyphellae, $0.1-0.2 \mathrm{~mm}$ long and 0.05-0.1 broad; brown, shiny, cylindrical to flattened. Secondary chemistry: no substances detected by TLC; medulla and cyphellae $\mathrm{K}$-.

Etymology. This new species is dedicated to Timothy Flynn, Curator at the herbarium (PTBG) of the National Tropical Botanical Garden and co-collector of the type material.

Distribution and ecology. Sticta flynnii has only been found twice at the type locality, growing in undisturbed montane forest at mid elevations (between 1000 and $1500 \mathrm{~m}$ ) on shaded tree bark. An older collection comes from Haleakalā National Park on Maui, indicating a distribution and ecology similar to those of $S$. antoniana, S. emmanueliana and $S$. hawaiiensis. Like several other new species described here, due to its small size this taxon likely has been overlooked and might be more common.

Notes. Sticta flynnii is one of three new Hawaiian species, and putative endemics, clustering in an early diverging clade close to $S$. gracilis and S. cyphellulata (Fig. 2; Fig. S1). Quite a number of cyanobacterial species in the genus share the caulescent morphology with marginal isidia, beside S. cyphellulata also S. brevipes, S. hypochra, S. longipes and S. marginifera (Galloway 1994b, 1998). All differ in morphological details such as size, the robustness and degree of branching of the thallus and the nature of the isidia. Sticta flynnii is a smaller species compared to the others mentioned here but it produces among the largest cyphellae, reaching up to $3 \mathrm{~mm}$ in diam. (usually up to $1 \mathrm{~mm}$ in the other species). This feature also distinguishes it from the closely related $S$. smithii.

Phylogenetically, Sticta flynnii is supported sister to $S$. gracilis (Japan). The two clades differ substantially 

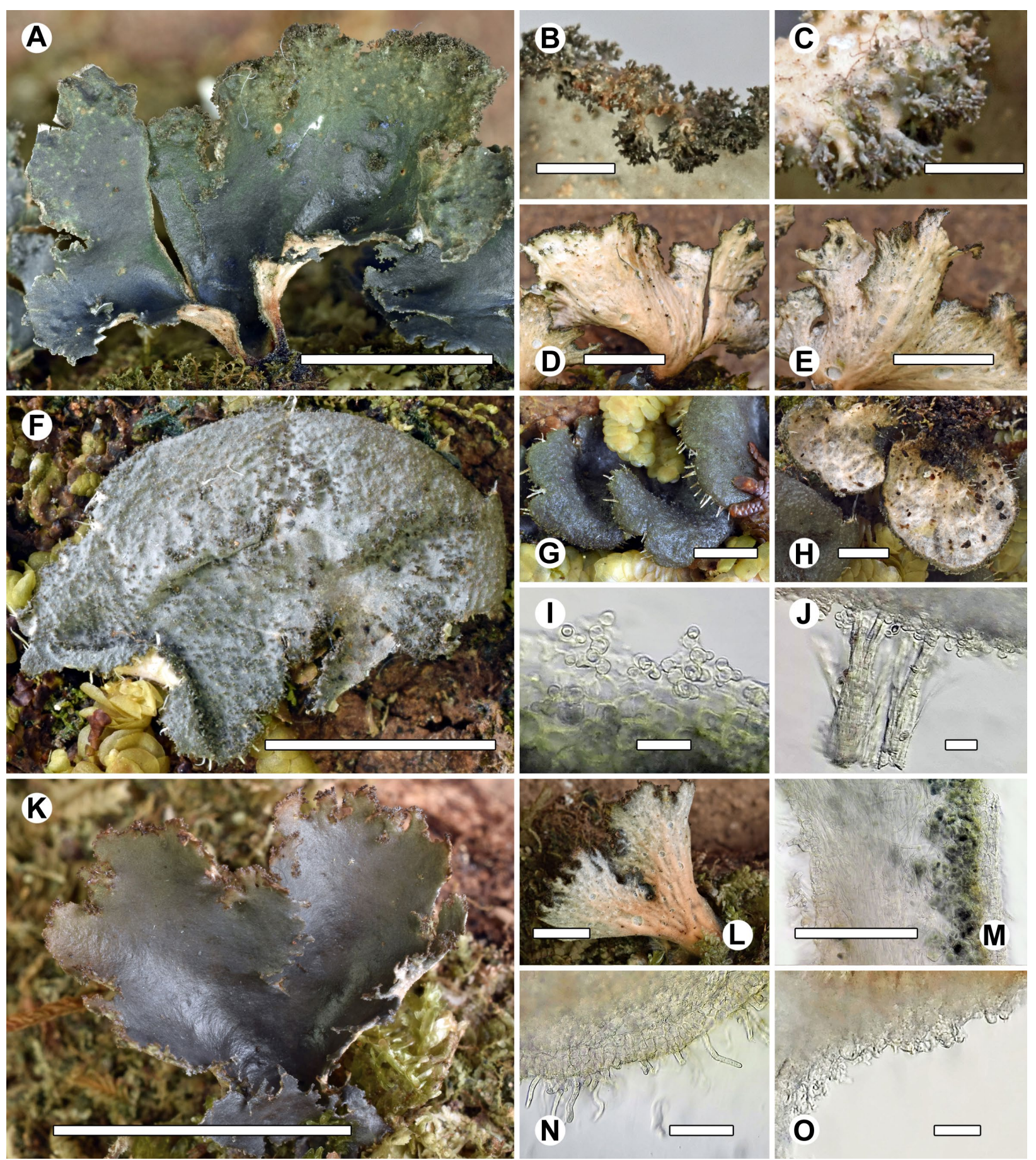

Figure 5. Morphology and anatomy of new Hawaiian Sticta species. A-E - S. flynnii (A, thallus; B-C, marginal arbuscular isidia seen from above and below; D-E, lobe underside showing large cyphellae); F-J - S. hawaiiensis (F, mature thallus lobe showing laminal isidia; G, young lobes with conspicuous white cilia; $\mathrm{H}$, lobe underside showing minute cyphellae; I, section through lobe showing upper surface tomentum; J, section through lobe showing fascicle of lower surface primary tomentum); K-O - S. smithii (K, thallus with marginal isidia; L, lobe underside showing minute cyphellae; $\mathrm{M}$, section through lobe; $\mathrm{N}$, section through lobe showing secondary tomentum; $\mathrm{O}$, section through membrane of cyphella showing papillae). Scales: A, D-F, K $=5 \mathrm{~mm}, \mathrm{G}-\mathrm{H}, \mathrm{L}=1 \mathrm{~mm} ; \mathrm{B}-\mathrm{C}=0.5 \mathrm{~mm} ; \mathrm{M}=100 \mu \mathrm{m} ; \mathrm{N}=50 \mu \mathrm{m} ; \mathrm{I}-\mathrm{J}, \mathrm{O}=10 \mu \mathrm{m}$.

in 12 substitutions and 23 indels in the ITS (Table 2; Fig. S1).

Additional specimen examined. USA. Hawaii: Maui, East Maui, Haleakalā Volcano, Haleakalā National Park, 1/8 mile E of Hosmer's Grove campsite; 2233 m; deep gully with steep sides, on dead twigs of Dodonea $1 \mathrm{~m}$ above ground in open position; 12 June 1975, C. W. Smith 1754 (HAW). Kauai, West Kauai, western slopes of Mount Wai'ale'ale, Koke'e State Park, 20 km ENE of Waimea and $35 \mathrm{~km}$ NW of Lihue, at end of Kokee Road,
Pihea Trail; $22^{\circ} 08^{\prime} 51^{\prime \prime} \mathrm{N}, 159^{\circ} 37^{\prime} 53^{\prime \prime} \mathrm{E}, 1250-1350 \mathrm{~m}$; mostly undisturbed montane mesic forest, on tree bark; 15 June 2013, B. Moncada, R. Lücking \& T. Flynn 7059 (HAW - paratype!).

Sticta hawaiiensis Moncada \& Lücking, sp. nov.

(Fig. 5F-J)

MycoBank MB 835290

Diagnosis: A small, epiphytic Sticta with cyanobacterial photobiont, with largely unbranched, suborbicular, bluish to brownish 
grey thallus with laminal, coralloid isidia, with conspicuous white cilia, and with pale underside producing small cyphellae.

Type: USA, Hawaii: Kauai, West Kauai, western slopes of Mount Wai'ale'ale, Koke'e State Park, 20 km ENE of Waimea and $35 \mathrm{~km} \mathrm{NW}$ of Lihue, at end of Kokee Road, Pihea Trail; $22^{\circ} 08^{\prime} 51^{\prime \prime} \mathrm{N}, 159^{\circ} 37^{\prime} 53^{\prime \prime} \mathrm{E}, 1250-1350 \mathrm{~m}$; mostly undisturbed montane mesic forest, on tree bark; 15 June 2013, B. Moncada, R. Lücking \& T. Flynn 7048 (F - holotype!; HAW - isotype!).

ITS barcoding sequences: MT132716 (holotype), MT132672 (paratype).

Description. Epiphytic on bark covered with bryophyte mats; primary photobiont cyanobacterial (Nostoc). Stipe indistinct (in young thalli) to absent. Thallus mono- to polyphyllous, with one to few individual thalli arranged irregularly, groups of individual thalli up to $5 \mathrm{~cm}$ across; individual thalli delicate, unbranched; lobes suborbicular, ascending, not usually overlapping, plane to revolute, margins entire to irregular, not thickened; lobes $0.2-0.5 \mathrm{~cm}$ long, $0.5-1 \mathrm{~cm}$ broad. Upper surface irregularly verruculose-rugose in concentric patterns, dark grey when fresh, rather dark bluish grey in the herbarium, matte; surface very thinly whitish tomentose, without or with scattered papillae, without pruina, without distinct maculae; marginal cilia abundant and distinct, particularly in younger thalli, white, $0.2-0.7 \mathrm{~nm}$ long, usually curved slightly downwards and often flattened. Lower surface slightly uneven, white to cream-colored; primary tomentum present (except for margins), forming scattered (towards center more densely arranged), mottled brown tufts of fasciculate hyphae; secondary tomentum developed up to margins, thin, pubescent, white. Rhizines absent. Cyphellae scattered, 1-20 per $\mathrm{cm}^{2}$, rounded, plane, immersed to becoming erumpent (best seen when thallus hydrated), white; pore $0.1-0.2 \mathrm{~mm}$ diam. Medulla lax, white. Upper cortex paraplectenchymatous, 15-20 $\mu \mathrm{m}$ thick, uniform, consisting of 1-2 cell layers with cells 5-10 $\mu \mathrm{m}$ diam., their walls $1-2 \mu \mathrm{m}$ thick and their lumina rounded to isodiametric, 3-8 $\mu \mathrm{m}$ diam. Photobiont layer 20-30 $\mu \mathrm{m}$ thick, its cells 5-10 $\mu \mathrm{m}$ diam. Medulla 30-50 $\mu \mathrm{m}$ thick, its hyphae 2-2.5 $\mu \mathrm{m}$ broad, nubilous due to enclosed air. Lower cortex paraplectenchymatous, 10-20 $\mu \mathrm{m}$ thick, with single cell layer; cells $7-12 \mu \mathrm{m}$ diam., their walls $1-1.5 \mu \mathrm{m}$ thick. Hairs of upper tomentum $10-20 \mu \mathrm{m}$ long, of single, branched, moniliform hyphae with free apices. Hairs of lower primary tomentum 100-150 $\mu \mathrm{m}$ long, in fascicles of 10-20, mostly unbranched but agglutinate, cylindrical hyphae with free apices; hairs of lower secondary tomentum 10-15 $\mu \mathrm{m}$ long, of single, branched, strongly moniliform hyphae with globose cells and free apices. Cells of basal membrane of cyphellae irregularly bulging, with numerous tiny papillae per cell. Apothecia not observed. Isidia present, abundant, laminal, branched and becoming coralloid; clusters of isidia up to $0.2 \mathrm{~mm}$ long and broad, rather dark grey to brownish grey, shiny, cylindrical. Secondary chemistry: no substances detected by TLC; medulla and cyphellae $\mathrm{K}-$.

Etymology. The epithet refers to the archipelago of Hawaii, as this new species is a putative endemic in a highly derived, apparently subcosmopolitan species complex.
Distribution and ecology. Besides Sticta antoniana and $S$. emmanueliana, this is a third species with a similar ecology, having been found at the same two localities on the islands of Maui and Kauai, in both cases in more or less undisturbed montane forest at mid elevations (between 1000 and $1500 \mathrm{~m}$ ), on shaded tree bark. Another, older collection stems from Oahu, in a more disturbed habitat.

Notes. The Sticta ciliata complex is one of more than a dozen mostly unrelated lineages that exhibit $S$. fuliginosa morphology, with broadly rounded lobes featuring laminal isidia and generally a pale underside. This distinctive lineage was first recognized in a broad phylogenetic analysis by Moncada et al. (2014a), based on material from Colombia, but Magain \& Sérusiaux (2015) eventually established that $S$. ciliata, described from Ireland, is a representative of this clade. The data now available characterize this clade as a species complex, with uniform morphology and anatomy (small size; broad, laminally isidiate lobes; marginal whitish cilia; cells of the cyphella membrane with numerous tiny papillae).

The complex has been shown to be present in Western Europe, the Neotropics, and now Hawaii. It forms several distinct lineages (Fig. 2; Fig. S1): two chiefly in South America, two in Western Europe (one including the type), two in the Caribbean (Puerto Rico; recently described as S. parvilobata; Mercado-Díaz et al. 2020) and one in Hawaii. The Hawaiian taxon S. hawaiiensis appears to be most closely related to $S$. aff. parvilobata from Puerto Rico, from which it differs in only one substitution, whereas S. parvilobata s.str. (also Puerto Rico) differs in ten substitutions. Sticta ciliata s.str. deviates in six substitutions, whereas the other, unnamed clades exhibit differences between three and six substitutions and between zero and two indels in the ITS (Table 2; Fig. 6). It therefore seems prudent to formally recognize the Hawaiian material as a distinct taxon, as the two named species in this complex show substantial differences, whereas the more similar lineages have not yet been named. Given the difference of only one substitution between $S$. hawaiiensis and the Puerto Rican $S$. aff. parvilobata, the latter could be considered to represent the same species, which would be a remarkable disjunction in this clade. However, the substitution present in $S$. aff. parvilobata is unique among all lineages in the entire clade (Fig. 6) and therefore we consider it unlikely that this lineage is conspecific with $S$. hawaiiensis. Overall, S. ciliata s.lat. appears to represent a relatively recent radiation in active, phenotypically cryptic speciation but with a distinct geographic signal (Magain \& Sérusiaux 2015; Mercado-Díaz et al. 2020).

Additional specimen examined. USA. Hawaii: Oahu, Koolau Mountains, Tantalus; 467 m; exposed ridge, on Cordyline terminalis; 26 July 1977, G. Y. Daida 520 (HAW). Maui, East Maui, Haleakalā Volcano, Lower Waikamoi Preserve (The Nature Conservancy), $5 \mathrm{~km}$ SE of Pulakani and $18 \mathrm{~km} \mathrm{SE}$ of Kahului, lower access trail to preserve off Olinda Road; $20^{\circ} 48^{\prime} 23^{\prime \prime} \mathrm{N}, 156^{\circ} 15^{\prime} 19^{\prime \prime} \mathrm{E}, 1200-1300 \mathrm{~m}$; disturbed primary forest dominated by Acacia koa and Campanulaceae, with invasive Hedychium gardnerianum in lower portions; on tree 


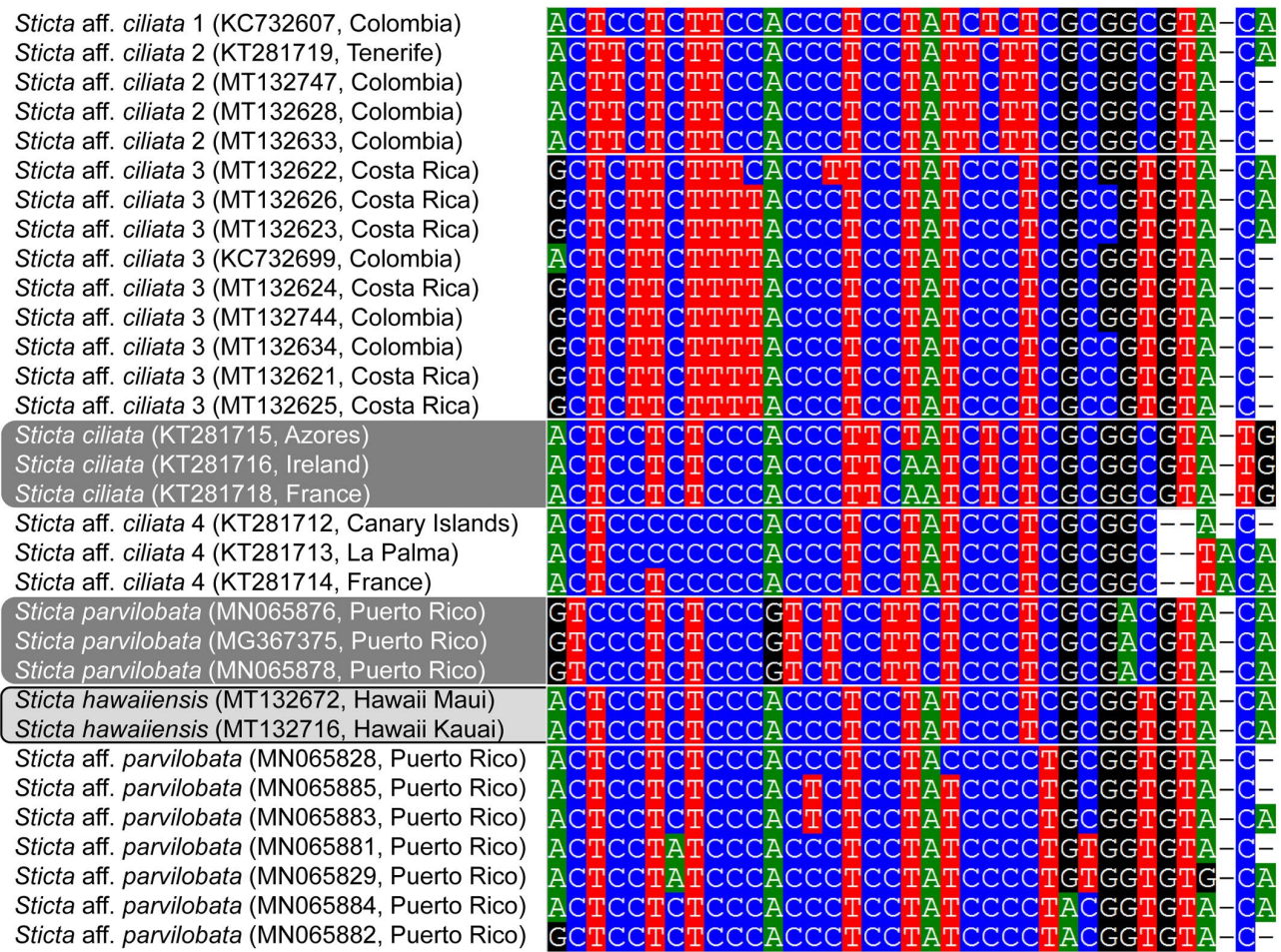

Figure 6. Comparison of variable sites in the fungal ITS barcoding marker in the Sticta ciliata complex (screenshot from BIOEDIT). All constant columns and the few autapomorphic, parsimony-uninformative singleton sites were deleted. Formally named taxa are highlighted. Note that the variation is structured in blocks that largely correlate with geography. The Hawaiian lineage is most similar to two unnamed lineages, namely $S$. aff. ciliata 4 (four substitutions) and $S$. aff. parvilobata (one substitution). While the difference towards S. parvilobata appears minor, it corresponds to two unique substitutions in the latter not present in any of the other lineages.

bark, 11 June 2013, B. Moncada, R. Lücking \& P. Bily 6953 (B, F, HAW - paratypes!).

Sticta smithii Moncada \& Lücking, sp. nov. (Fig. 5K-O)

\section{MycoBank MB 835291}

Diagnosis: A diminutive, epiphytic, stipitate Sticta with a cyanobacterial photobiont, marginal, arbuscular, typically flattened isidia, and a pale underside with small cyphellae.

Type: USA, Hawaii: Oahu, Koolau Range, Manoa Valley, $6 \mathrm{~km}$ ENE of Honolulu and $8 \mathrm{~km}$ WSW of Kaneohe, Manoa Cliffs Trail, Moleka Trailhead to Forestry Exclosure: $21^{\circ} 19^{\prime} 55^{\prime \prime} \mathrm{N}$, $157^{\circ} 48^{\prime} 43^{\prime \prime} \mathrm{E}, 410-575 \mathrm{~m}$; partially disturbed secondary forest with some exposed vegetation and some planted trees, on tree root between bryophytes; 9 June 2013, B. Moncada, R. Lücking \& C. Smith 6916 (F - holotype!; B, HAW - isotypes!).

ITS barcoding sequences: MG754196 (holotype).

Description. Epiphytic on bark covered with bryophyte mats; primary photobiont cyanobacterial (Nostoc). Stipe present, short. Thallus monophyllous, with few individual thalli arranged irregularly, groups of individual thalli up to $3 \mathrm{~cm}$ across; individual thalli delicate, irregularly branched and dissected, with $2-4$ branches per $5 \mathrm{~cm}$ radius; lobes spathuliform to truncate, ascending, not usually overlapping, plane to involute, margins becoming strongly dissected, not thickened; lobe internodes $0.3-0.6 \mathrm{~cm}$ long, $0.2-0.5 \mathrm{~cm}$ broad. Upper surface even, olive-grey when fresh, bluish grey in the herbarium, matte; surface glabrous, without papillae, without pruina, with scattered white maculae; marginal cilia absent. Lower surface uneven, forming shallow, vein-like ridges in longitudinal direction, white to cream-colored, with pale orange streaks towards center; primary tomentum present, dense but very short, becoming shorter towards margins, whitish; secondary tomentum absent. Rhizines absent. Cyphellae rather dense, $21-40$ per $\mathrm{cm}^{2}$, rounded to irregular, plane, immersed, white; pore $0.2-0.5 \mathrm{~mm}$ diam. Medulla lax, white. Upper cortex paraplectenchymatous, $20-30 \mu \mathrm{m}$ thick, uniform, consisting of 2-3 cell layers with cells $4-8 \mu \mathrm{m}$ diam., their walls $1-2 \mu \mathrm{m}$ thick and their lumina rounded to isodiametric, 3-6 $\mu \mathrm{m}$ diam., the innermost layer having larger cells. Photobiont layer 40-60 $\mu \mathrm{m}$ thick, its cells 5-10 $\mu \mathrm{m}$ diam. Medulla 100$150 \mu \mathrm{m}$ thick, its hyphae $2-2.5 \mu \mathrm{m}$ broad, nubilous due to enclosed air and grey crystals. Lower cortex paraplectenchymatous, 20-30 $\mu \mathrm{m}$ thick, with 1-2 cell layers; cells 5-10 $\mu \mathrm{m}$ diam., their walls $1-2 \mu \mathrm{m}$ thick. Hairs of lower primary tomentum 50-100 $\mu \mathrm{m}$ long, of single to agglutinate, mostly unbranched, cylindrical, colorless hyphae with free apices. Cells of basal membrane of cyphellae irregularly bulging, each cell with 1-3 elongated papillae, therefore appearing thorny. Apothecia not observed. Isidia present, abundant, predominantly marginal, arbuscular, much-branched and becoming coralloid; arbusculae up to $1 \mathrm{~mm}$ long and broad, distinctly flattened, with the base of thallus color and lacking cyphellae, individual isidia 0.1-0.2 mm long and 0.05-0.1 broad; grey-brown, shiny, typically flattened. Secondary chemistry: no substances detected by TLC; medulla and cyphellae K-.

Etymology. The epithet honors Clifford Smith for his invaluable contributions to our knowledge of Hawaiian 
lichens and for his tireless conservation efforts to preserve native Hawaiian ecosystems, including its lichens (Smith 1991; Tunison et al. 1992; Ellshoff et al. 1995; Smith 2002; Rohrer et al. 2006).

Distribution and ecology. Like Sticta acyphellata, this new species was only found in a partially disturbed secondary forest on the densely populated and strongly altered island of Oahu, where it grew epiphytic in shaded conditions on tree trunks between bryophytes.

Notes. Sticta smithii is overall most similar to S. flynnii, sharing the small, stipitate, cyanobacterial thallus with marginal isidia and the cyphellate underside. A major difference is the size of the cyphellae, becoming large and irregular in S. flynnii but remaining diminutive in S. smithii. Also, the distribution and ecology of the two species appear to differ, as judged from the limited data.

Phylogenetically, Sticta flynnii is not directly related to $S$. flynnii but is supported sister to $S$. cyphellulata (China). The two clades differ substantially in 15 substitutions and 11 indels in the ITS (Table 2; Fig. S1).

\section{Sticta waikamoi Moncada \& Lücking, sp. nov.}

(Fig. 7A-F)

\section{MycoBank MB 835292}

Diagnosis: A small to mid-sized epiphytic Sticta with a cyanobacterial photobiont, a brownish, much-branched thallus with slighly canaliculate lobes and marginal, coralloid isidia, and a thick, dark brown lower tomentum with strongly contrasting, conspicuous, whitish cyphellae.

Type: USA, Hawaii: Maui, East Maui, Haleakalā Volcano, Upper Waikamoi Preserve (The Nature Conservancy), $12 \mathrm{~km}$ SE of Pulakani and $25 \mathrm{~km}$ SE of Kahului, upper access trail to preserve bordering Haleakalā National Park; $20^{\circ} 46^{\prime} 07^{\prime \prime} \mathrm{N}$, $156^{\circ} 14^{\prime} 17^{\prime \prime} \mathrm{E}, 1800-2100 \mathrm{~m}$; introduced mixed conifer forest intermingled with Acacia koa and other native trees; 12 June 2013, B. Moncada, R. Lücking \& P. Thomas 7000 (F - holotype!; B, HAW - isotypes!).

ITS barcoding sequences: MT132696 (holotype).

Description. Epiphytic over bryophytes; primary photobiont cyanobacterial (Nostoc). Stipe absent. Thallus monophyllous, irregularly orbicular, up to $7 \mathrm{~cm}$ across, anisotomously branched, with 3-5 branches per $5 \mathrm{~cm}$ radius; lobes elongate to narrowly flabellate, more or less horizontal, not usually overlapping, involute to shallowly canaliculate, margins entire to broadly crenulate, not thickened; lobe internodes $0.5-1.5 \mathrm{~cm}$ long, $0.3-0.5 \mathrm{~cm}$ broad. Upper surface even, olive-grey to grey-brown when fresh, light yellowish to greyish brown in the herbarium, matte; surface glabrous, without papillae, without pruina, without distinct maculae; marginal cilia not differentiated but lower tomentum often projecting beyond margins to resemble short, brown-black cilia. Lower surface slightly uneven, dark brown; primary tomentum thick and dense, forming dark brown, arachnoid tufts of fasciculate hyphae; secondary tomentum not discernable. Rhizines scattered towards thallus center. Cyphellae rather dense, 21-60 per $\mathrm{cm}^{2}$, rounded, plane, immersed to becoming erumpent, white to cream-colored, strongly contrasting with the dark tomentum; pore 0.3-1(-1.5) mm diam. Medulla lax, white. Upper cortex paraplectenchymatous, 30-50 $\mu \mathrm{m}$ thick, differentiated, consisting of 3-5 cell layers, the upper 1-2 layers with cells 3-5 $\mu \mathrm{m}$ diam., their walls $1-2 \mu \mathrm{m}$ thick and their lumina rounded to isodiametric, 2-3 $\mu \mathrm{m}$ diam., yellowish, the lower 2-3 layers with cells $5-10 \mu \mathrm{m}$ diam., their walls $1-1.5 \mu \mathrm{m}$ thick and their lumina isodiametric, 4-9 $\mu \mathrm{m}$ diam., colorless. Photobiont layer 50-70 $\mu \mathrm{m}$ thick, forming vertical (perpendicular) clusters, its cells 5-10 $\mu \mathrm{m}$ diam. Medulla $30-50 \mu \mathrm{m}$ thick, its hyphae 2-2.5 $\mu \mathrm{m}$ broad, nubilous due to enclosed air. Lower cortex paraplectenchymatous, 20-30 $\mu \mathrm{m}$ thick, with 2-3 cell layers; cells 7-12 $\mu \mathrm{m}$ diam., their walls $1-2 \mu \mathrm{m}$ thick, becoming brown towards margin. Hairs of lower primary tomentum 100-300 $\mu \mathrm{m}$ long, in fascicles of 10-20, mostly unbranched but strongly agglutinate, dark brown, cylindrical hyphae with free apices; hairs of lower secondary tomentum 20-30 $\mu \mathrm{m}$ long, of single, branched, weakly moniliform hyphae with slightly inflated cells and free apices. Cells of basal membrane of cyphellae irregularly bulging but lacking papillae. Apothecia not observed. Isidia present, abundant, predominantly marginal, branched and becoming coralloid; clusters of isidia up to $0.5 \mathrm{~mm}$ long and broad, grey-brown, shiny, individual isidia usually flattened. Secondary chemistry: no substances detected by TLC; medulla $\mathrm{K}$ - to slowly $\mathrm{K}+$ faintly yellowish, cyphellae $\mathrm{K}+$ slowly ochraceous.

Etymology. The epithet is a noun in apposition referring to the Waikamoi Preserve (The Nature Conservancy), the largest private nature reserve in the state of Hawaii.

Distribution and ecology. This new species is so far only known from a single collection, found at high altitude in mixed conifer forest. In spite of the well-preserved appearance of this forest, no conifer is native to Hawaii and all have been introduced. It is therefore difficult to speculate about the ecology of this species. Its closest relatives, $S$. aff. cordillerana, $S$. rhizinata and $S$. aff. rhizinata, are from North and South America (McDonald et al. 2003; Moncada \& Lücking 2012; Moncada et al. 2014a).

Notes. Sticta waikamoi is one of two species in Hawaii (the other being $S$. andina) best corresponding to the morphology of what has been called $S$. weigelii. The latter species in a strict sense appears to be a Neotropical taxon and is not directly related (Fig. S1); it differs in the thinner lower tomentum and the often yellow cyphellae. In Hawaii, $S$. waikamoi can be confused with $S$. andina, which is found in the same habitat, but differs in the generally narrower lobes and is also not directly related (Fig. 2; Fig. S1). Although S. waikamoi is closely related to $S$. rhizinata, it appears to be a much smaller species, and rhizines, a characteristic feature of the latter (Moncada \& Lücking 2012), are sparse and not conspicuous.

Phylogenetically, the new species forms part of a complex of four lineages, including Sticta rhizinata from Colombia and two as yet undescribed taxa from Colombia and North America (Fig. S1). Overall, S. waikamoi differs from $S$. rhizinata in four substitutions, and from the other two taxa in six to seven substitutions and up to 

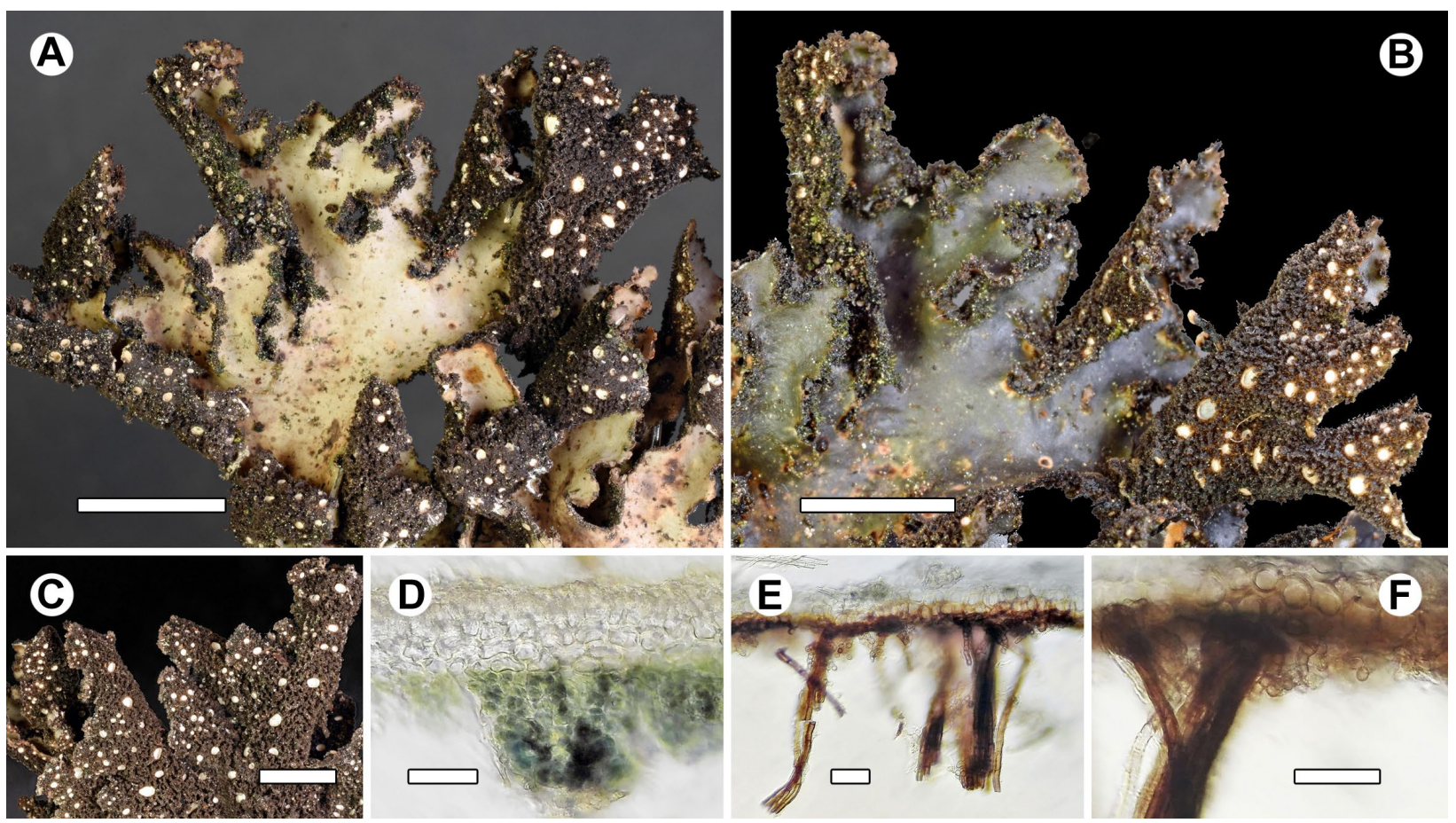

Figure 7. Morphology and anatomy of new Hawaiian Sticta species. A-F - S. waikamoi (A-C, dry and wet lobes showing marginal isidia and dark lower tomentum contrasting with whitish cyphellae; D, section through thallus showing vertically organized groups of photobiont cells; E-F; section through thallus showing lower primary and secondary tomentum). Scales: A-C $=1 \mathrm{~mm}$; D-F $=20 \mu \mathrm{m}$.

one indel. Given these limited differences, one may also consider the alternative of applying subspecies level to the Hawaiian material. However, compared to the case of S. scabrosa subsp. hawaiiensis (Moncada et al., unpublished), there are twice as many differences in the ITS between $S$. waikamoi and $S$. rhizinata (Table 2) and these correlate with the deviating morphology. We therefore consider species level to be more appropriate, and we apply it also to raise awareness of this apparently very rare taxon until it can be studied from more material.

\section{Acknowledgements}

$\mathrm{BM}$ and RL are grateful to Clifford Smith (Oahu Army Natural Resource Program) for his support and guidance during their visit to Hawaii and particularly Oahu. Patrick Bily (The Nature Conservancy Hawaii), Timothy Flynn (National Tropical Botanical Garden), Daniel Pomaika'i (Maui Soil and Water Conservation Districts, Maunalai Arboretum) and Philip Thomas (Research Corporation of the University of Hawaii and the Hawaiian Ecosystems at Risk Project) provided invaluable field assistance on Maui and Kauai and shared their profound knowledge of Hawaiian ecosystems and fauna and flora. The aforementioned institutions, as well as Jill Kajikawa-kent (University of Hawaii) and Rae Matthews and the Clark family (National Tropical Botanical Garden), assisted with logistics. The Hawaii Department of Land \& Natural Resources, Divisions of Forestry and Wildlife and Division of State Parks, kindly provided collecting and research permits. Chelsea Carineo, Wendee Kokubun, Ryan Peralta, Patrick Porter, Matthew Rittenhouse and Lancede Silva are thanked for processing permit requests. Konstanze Bensch assisted with MycoBank registration of the nomenclatural novelties, and the GenBank Direct Submission staff promptly provided the GenBank Accession numbers. We thank Bernard Goffinet and two anonymous reviewers for comments that helped to improve the manuscript. Funding for field and laboratory work was provided by two grants from the National Science Foundation (NSF) to The Field Museum: ATM - Assembling a Taxonomic Monograph: The Lichen Family Graphidaceae (DEB-1025861; PI HTL, CoPI RL), and Collaborative Research: Evolution, Diversification, and Conservation of a Megadiverse Flagship Lichen Genus (DEB-1354884; PI HTL, CoPI RL). Sequence data for Sticta cyphellulata were provided by Bernard Goffinet and Dinah Parker, through the sister project Collaborative Research: Evolution, Diversification, and Conservation of a Megadiverse Flagship Lichen Genus (DEB-1354631; PI B. Goffinet), based on specimens kindly provided by Li-Song Wang. Additional funding for this study was obtained from the Field Museum's Women's Board Field Dreams program 2011, through gifts by the Robert Thomas Bobins Foundation through Mrs. Virginia Bobins (Chicago), Mr. and Mrs. John Borland Jr. (Chicago), Mrs. Peggy Carr (Chicago) and Mrs. Sue Dickes (Winnetka).

\section{Supplementary electronic material}

Figure S1. Best-scoring ML circle tree of Sticta based on the ITS barcoding marker. Hawaiian specimens are marked in blue (exclusive Hawaiian clades) and orange (Hawaiian specimens nested within more widely distributed taxa). Bootstrap values are indicated above branches. Download file

Table S1. Genbank accession numbers of ITS sequences of non-Hawaiian (or previously accessioned) representatives of Sticta (and outgroup) used in this study. Download file

File S1. Alignment of the fungal ITS barcoding marker for 859 OTUs of Sticta used in this study (Fasta format). Download file

\section{References}

Ahti, T. 1987. Endemism among Cladoniaceae in the Table Mountains of the Guayana Highland, Venezuela. Bibliotheca Lichenologica 25: 419-420.

Ahti, T. \& Aptroot, A. 1992. Lichens of Madagascar: Cladoniaceae. Cryptogamie, Bryologie-Lichénologie 13: 117-124. 
Antoine, M. E. 2004. An ecophysiological approach to quantifying nitrogen fixation by Lobaria oregana. The Bryologist 107: 82-87.

Aptroot, A. 2016. Preliminary checklist of the lichens of Madagascar, with two new thelotremoid Graphidaceae and 131 new records. Willdenowia 46: 349-366.

Baldwin, B. G. \& Sanderson, M. J. 1998. Age and rate of diversification of the Hawaiian silversword alliance (Compositae) Proceedings of the National Academy of Sciences of the United States of America 95: 9402-9406.

Baldwin, B. G., Kyhos, D. W., Dvorak, J. \& Carr, G. D. 1991. Chloroplast DNA evidence for a North American origin of the Hawaiian silversword alliance (Asteraceae). Proceedings of the National Academy of Sciences of the United States of America 88: 1840-1843.

Barrier, M., Robichaux, R. H. \& Purugganan, M. D. 2001. Accelerated regulatory gene evolution in an adaptive radiation. Proceedings of the National Academy of Sciences of the United States of America 98: 10208-10213.

Becker, V. E. 1980. Nitrogen fixing lichens in forests of the Southern Appalachian Mountains of North Carolina. The Bryologist 83: 29-39.

Beckett, R. P. 1995. Some aspects of the water relations of lichens from habitats of contrasting water status studied using thermocouple psychrometry. Annals of Botany 76: 211-217.

Benner, J. W. \& Vitousek, P. M. 2012. Cyanolichens: a link between the phosphorus and nitrogen cycles in a Hawaiian montane forest. Journal of Tropical Ecology 28: 73-81.

Benner, J. W., Conroy, S., Lunch, C. K., Toyoda, N. \& Vitousek, P. M. 2007. Phosphorus fertilization increases the abundance of nitrogenase activity of the cyanolichen Pseudocyphellaria crocata in Hawaiian montane forests. Biotropica 39: 400-405.

Bock, C., Hauck, M. \& Fischer, E. 2007. The lichen flora of Rwanda: an annotated checklist. Willdenowia 37: 563-575.

Brodo, I. M., Sharnoff, S. D. \& Sharnoff, S. 2001. Lichens of North America. Yale University Press, New Haven \& London.

Brown, G. K., Murphy, D. J., Kidman, J. \& Ladiges, P. Y. 2012. Phylogenetic connections of phyllodinous species of Acacia outside Australia are explained by geological history and human-mediated dispersal. Australian Systematic Botany 25: 390-403.

Carlquist, S., Baldwin, B. G. \& Carr, G. D. (eds) 2003. Tarweeds \& Silverswords: Evolution of the Madiinae (Asteraceae). Missouri Botanical Garden Press, St. Louis, Missouri.

Casacci, L. P., Barbero, F. \& Balletto, E. 2014. The 'Evolutionarily Significant Unit' concept and its applicability in biological conservation. Italian Journal of Zoology 81: 182-193.

Cornejo, C., Derr, C. \& Dillman, K. 2017. Ricasolia amplissima (Lobariaceae): one species, three genotypes and a new taxon from south-eastern Alaska. The Lichenologist 49: 579-596.

Delise, D. 1825. Histoire de Lichens. Genre Sticta. Caen.

Drummond, A. J. \& Rambaut, A. 2007. BEAST: Bayesian evolutionary analysis by sampling trees. BMC Evolutionary Biology 7: 214

Drummond, A. J., Suchard, M. A., Xie, D. \& Rambaut, A. 2012. Bayesian phylogenetics with BEAUti and the BEAST 1.7. Molecular Biology and Evolution 29: 1969-1973.

Ekman, S., Tønsberg, T. \& Jørgensen, P. M. 2019. The Sticta fuliginosa group in Norway and Sweden. Graphis Scripta 31: 23-33.

Eldredge, L. G. \& Miller, S. E. 1995. How many species are there in Hawaii? Bishop Museum Occasional Papers 41: 3-18.

Eliasaro, S., Gerlach, A. D. C. L. \& Gumboski, E. L. 2012. Novos registros de fungos liquenizados para o estado do Paraná, Brasil. Revista Brasileira de Biociências 10: 507-512.

Elix, J. A. \& McCarthy, P. M. 1998. Catalogue of the lichens of the smaller Pacific Islands. Bibliotheca Lichenologica 70: 1-361.

Elix, J. A. \& McCarthy, P. M. 2008. Checklist of Pacific Island Lichens. https://www.anbg.gov.au/abrs/lichenlist/PACIFIC introduction.html [accessed 27 November 2019].
Ellshoff, Z. E., Gardner, D. E., Wikler, C. \& Smith, C. W., 1995. Annotated bibliography of the genus Psidium, with emphasis on $P$. cattleianum (strawberry guava) and $P$. guajava (common guava), forest weeds in Hawai'i. Technical Report 95, Department of Botany, Cooperative National Park Resources Studies Unit, University of Hawaii at Manoa.

Esslinger, T. L. 1978. Studies in the lichen family Physciaceae. III A new species of Phaeophyscia from Hawaii. Mycologia 70: 1247-1249.

Evenhuis, N. L. \& Eldredge, L. G. (eds) 2002. Records of the Hawaii Biological Survey. Part 1: Articles. Bishop Museum Occasional Papers 68: 1-78

Feuerer, T. \& Hawksworth, D. L. 2007. Biodiversity of lichens, including a world-wide analysis of checklist data based on Takhtajan's floristic regions. Biodiversity and Conservation 16: 85-98.

Fleischer, R. C., McIntosh, C. E. \& Tarr, C. L. 1998. Evolution on a volcanic conveyor belt: using phylogeographic reconstructions and $\mathrm{K}-\mathrm{Ar}$-based ages of the Hawaiian Islands to estimate molecular evolutionary rates. Molecular Ecology 7: 533-545.

Follmann, G. 1974. Zur Nomenclatur der Lichenen. I. Erganzungen und Neukombinationen. Philippia 2: 73-74.

Fosberg, E. R. 1936. The Hawaiian Geraniums. Occasional Papers of the Bernice P. Bishop Museum 12: 1-19.

Galloway, D. J. 1991. Biogeographical relationships of Pacific tropical lichen floras. In: Galloway, D. J. (ed.), Tropical Lichens: Their Systematics, Conservation, and Ecology, pp. 1-16. The Systematics Association Special Volume, Clarendon Press, Oxford.

Galloway, D. J. 1994a. Biogeography and ancestry of lichens and other ascomycetes. In: Hawksworth, D. L. (ed.), Ascomycete Systematics. Problems and Perspectives in the Nineties, pp. 175-184. NATO Advanced Science Institutes Series, Plenum Press, New York.

Galloway, D. J. 1994b. Studies on the lichen genus Sticta (Schreber) Ach.: I. Southern South American species. The Lichenologist 26: $223-282$.

Galloway, D. J. 1995. Studies on the lichen genus Sticta (Schreber) Ach.: III. Notes on species described by Bory de St-Vincent, William Hooker, and Delise, between 1804 and 1825. Nova Hedwigia 61: $147-188$

Galloway, D. J. 1998. Studies on the lichen genus Sticta (Schreber) Ach.: V. Australian species. Tropical Bryology 15: 117-160.

Galloway, D. J. 2001. Sticta. In: McCarthy, P. M. (ed.), Flora of Australia. Volume 58A, Lichens 3, pp. 78-97. ABRS/CSIRO Australia, Melbourne.

Galloway, D. J. 2006. Notes on the holotype of Sticta damaecornis $\beta$ weigelii Ach. (= Sticta weigelii). The Lichenologist 38: 89-92.

Galloway, D. J. 2007. Flora of New Zealand Lichens. Revised Second Edition Including Lichen-Forming and Lichenicolous Fungi. Volume 2. Manaaki Whenua Press, Lincoln, New Zealand.

Galloway, D. J. 2008. Lichen biogeography. In: Nash, T. H. III (ed.), Lichen Biology. Second Edition, pp. 315-335. Cambridge University Press, Cambridge.

Gardes, M. \& Bruns, T. D. 1993. ITS primers with enhanced specificity for basidiomycetes - application to the identification of mycorrhizae and rust. Molecular Ecology 2: 113-118.

Geiger, J. M. O., Ranker, T. A., Neale, J. M. R. \& Klimas, S. T. 2007. Molecular biogeography and origins of the Hawaiian fern flora. Brittonia 59: 142-158.

Givnish, T. J., Millam, K. C., Theim, T. T., Mast, A. R., Patterson, T. B., Hipp, A. L., Henss, J. M., Smith, J. F., Wood, K. R. \& Sytsma, K. J. 2009. Origin, adaptive radiation, and diversification of the Hawaiian lobeliads (Asterales: Campanulaceae). Proceedings of the Royal Society of London, Series B 276: 407-416.

Green, T. G. A. \& Lange, O. L. 1991. Ecophysiological adaptations of the lichen genera Pseudocyphellaria and Sticta to south temperate rainforests. The Lichenologist 23: 267-282. 
Green, T. G. A., Horstmann, J., Bonnett, H., Wilkins, A. \& Silvester, W. B. 1980. Nitrogen fixation by members of the Stictaceae (Lichenes) of New Zealand. New Phytologist 84: 339-348.

Green, T. G. A., Snelgar, W. P. \& Brown, D. H. 1981. Carbon dioxide exchange in lichens. Carbon dioxide exchange through the cyphellate lower cortex of Sticta latifrons Rich. New Phytologist 88: 421-426.

Green, T. G. A., Snelgar, W. P. \& Wilkins, A. L. 1985. Photosynthesis, water relations and thallus structure of Stictaceae lichens. In: Brown, D. H. (ed.), Lichen Physiology and Cell Biology, pp. 57-75. Plenum Press, New York and London.

Guzmán, G., Quilhot, W. \& Galloway, D. J. 1990. Decomposition of species of Pseudocyphellaria and Sticta in a southern Chilean forest. The Lichenologist 22: 325-331.

Hall, T. 2011. BioEdit: an important software for molecular biology. GERF Bull of Biosciences 2: 60-61.

Hodkinson, B. P., Lendemer, J. C., McDonald, T. \& Harris, R. C. 2014. The Status of Sticta sylvatica, an 'Exceedingly Rare' Lichen Species, in Eastern North America. Evansia 31: 17-25.

Imada, C. T. (ed.) 2012. Hawaiian native and naturalized vascular plants checklist (December 2012 update). Bishop Museum Technical Report 60: 1-29, 7 appendices.

Inoue, M. 2002. Four Arctic-alpine or bipolar species of Lecidea (Lichenes) new to the Hawaii Islands. Bulletin of the National Science Museum (Tokyo), Series B (Botany) 28: 7-10.

Jørgensen, P. M. 1983. Distribution patterns of lichens in the Pacific region. Australian Journal of Botany, Supplemental Series 10: 43-66.

Jørgensen, P. M. 1994. Studies in the lichen family Pannariaceae VI: the taxonomy and phytogeography of Pannaria Del. s.lat. Journal of the Hattori Botanical Laboratory 76: 197-206.

Joshi, M. \& Awasthi, D. D. 1982. The lichen family Stictaceae in India and Nepal. Biological Memoirs 7: 165-190.

Katoh, K. \& Frith, M. C. 2012. Adding unaligned sequences into an existing alignment using MAFFT and LAST. Bioinformatics 28: 3144-3146.

Katoh, K. \& Standley, D. M. 2013. MAFFT multiple sequence alignment software version 7: improvements in performance and usability. Molecular Biology and Evolution 30: 772-780.

Kelly, B. B. \& Becker, V. E. 1975. Effects of light intensity and temperature on nitrogen fixation by Lobaria pulmonaria, Sticta weigelii, Leptogium cyanescens and Collema subfurvum. The Bryologist 78: $350-355$.

Kidd, S. E. 2005. Molecular Phylogenetics of the Hawaiian Geraniums. MSc Thesis, Bowling Green State University, Ohio.

Kistenich, S., Timdal, E., Bendiksby, M. \& Ekman, S. 2018. Molecular systematics and character evolution in the lichen family Ramalinaceae (Ascomycota: Lecanorales). Taxon 67: 871-904.

Klement, O. 1966. Zur Kenntnis der Flechtenflora und -vegetation des Hawaii-Archipels. Nova Hedwigia 11: 243-283.

Klement, O. 1968. Key to Hawaiian Lichens. Degener's Flora Hawaiiana 1: 1-6.

Lendemer, J. C. \& Goffinet, B. 2016. Sticta deyana: a new endemic photomorphic lichen from the imperiled Mid-Atlantic Coastal Plain of eastern North America. Systematic Botany 40. 933-941.

Louwhoff, S. H. J. J. 2001. Biogeography of Hypotrachyna, Parmotrema and allied genera (Parmeliaceae) in the Pacific Islands. Bibliotheca Lichenologica 78: 223-246.

Lücking, R. 2003. Takhtajan's floristic regions and foliicolous lichen biogeography: a compatibility analysis. The Lichenologist 35: 33-54.

Lücking, R. \& Kalb, K. 2001. New Caledonia, foliicolous lichens and island biogeography. Bibliotheca Lichenologica 78: 247-273.

Lücking, R., Hodkinson, B. P. \& Leavitt, S. D. 2017a ('2016'). The 2016 classification of lichenized fungi in the Ascomycota and Basidiomycota - Approaching one thousand genera. The Bryologist 119: 361-416.
Lücking, R., Moncada, B., McCune, B., Farkas, E. E., Goffinet, B., Parker, D., Chaves, J. L., Lőkös, L., Nelson, P. R., Spribille, T., Stenroos, S., Wheeler, T., Yanez-Ayabaca, A., Dillman, K., Gockman, O. T., Goward, T., Hollinger, J., Tripp, E. A., Villella, J., Álvaro-Alba, W. R., Arango, C. J., Cáceres, M. E. S., Coca, L. F., Printzen, C., Rodríguez, C., Scharnagl, K., Rozzi, R., Soto-Medina, E. \& Yakovchenko, L. S. 2017b. Pseudocyphellaria crocata (Ascomycota: Lobariaceae) in the Americas reveals to be ten species, and none of them is Pseudocyphellaria crocata. The Bryologist 120: 441-500.

Lücking, R., Moncada, B. \& Smith, C. W. 2017c. The genus Lobariella (Ascomycota: Lobariaceae) in Hawaii: late colonization, high inferred endemism, and three new species. The Lichenologist 49: 673-691.

Magain, N. \& Sérusiaux, E. 2015. Dismantling the treasured flagship lichen Sticta fuliginosa (Peltigerales) into four species in Western Europe. Mycological Progress 14: 97.

Magnusson, A. H. 1955. A catalogue of Hawaiian lichens. Arkiv för Botanik, Ser. 2, 3(10): 223-402.

Magnusson, A. H. \& Zahlbruckner, A. 1943. Hawaiian lichens I. The families Verrucariaceae to Peltigeraceae. Arkiv för Botanik 31A(1): $1-96$.

Magnusson, A. H. \& Zahlbruckner, A. 1944. Hawaiian lichens. II. The families Lecideaceae to Parmeliaceae. Arkiv för Botanik, 31A(6): $1-109$.

Magnusson, A. H. \& Zahlbruckner, A. 1945. Hawaiian lichens III. The families Usneaceae to Physciaceae. Index. Arkiv för Botanik, 32A(2): $1-89$.

Marbach, B. 2000. Corticole und lignicole Arten der Flechtengattung Buellia sensu lato in den Subtropen und Tropen. Bibliotheca Lichenologica 74: 1-384.

Marcano, V., Morales Méndez, A., Sipman, H. J. M. \& Calderon, L. 1996. A first checklist of the lichen-forming fungi of the Venezuelan Andes. Tropical Bryology 12: 193-235.

McDonald, T., Miadlikowska, J. \& Lutzoni, F. 2003. The lichen genus Sticta in the Great Smoky Mountains: a phylogenetic study of morphological, chemical, and molecular data. The Bryologist 106: 61-80.

Medina R., Johnson, M. G., Liu, Y., Wilding, N. J., Hedderson, T., Wickett, N. \& Goffinet, B. 2018. Evolutionary dynamism in bryophytes: phylogenomic inferences confirm rapid radiation in the family $\mathrm{Fu}$ nariaceae. Molecular Phylogenetics and Evolution 120: 240-247.

Mercado-Díaz, J. A., Lücking, R., Moncada, B., Widhelm, T. J. \& Lumbsch, H. T. 2020. Elucidating species richness in lichen fungi: the genus Sticta (Ascomycota: Peltigeraceae) in Puerto Rico. Taxon (in press).

Miller, M. A., Pfeiffer, W. \& Schwartz, T. 2010. Creating the CIPRES Science Gateway for inference of large phylogenetic trees. In: Proceedings of the Gateway Computing Environments Workshop (GCE), New Orleans, pp. 1-8.

Mitchell, A. A., Li, R., Brown, J. W., Schönberger, I. \& Wen, J. 2012. Ancient divergence and biogeography of Raukaua (Araliaceae) and close relatives in the southern hemisphere. Australian Systematic Botany 25: 432-446.

Moncada, B. 2012. El Género Sticta (Schreb.) Ach. en Colombia: Taxonomía, Ecogeografia e Importancia. Doctoral Dissertation, Universidad Nacional de Colombia, Bogotá D.C., Colombia.

Moncada, B. \& Lücking, R. 2012. Ten new species of Sticta and counting: Colombia as a hot spot for unrecognized diversification in a conspicuous macrolichen genus. Phytotaxa 74: 1-29.

Moncada, B., Lücking, R. \& Betancourt, L. 2013a. Phylogeny of the Lobariaceae (lichenized Ascomycota: Peltigerales), and a reappraisal of the genus Lobariella. The Lichenologist 45: 203-263.

Moncada, B., Coca, L. F. \& Lücking, R. 2013b. Neotropical members of Sticta (lichenized Ascomycota: Lobariaceae) forming photosymbiodemes, with the description of seven new species. The Bryologist 116: 169-200. 
Moncada, B., Lücking, R. \& Coca, L. F. 2013c. Six new apotheciate species of Sticta (lichenized Ascomycota: Lobariaceae) from the Colombian Andes. The Lichenologist 45: 635-656.

Moncada, B., Lücking, R. \& Suárez, A. 2014a. Molecular phylogeny of the genus Sticta (lichenized Ascomycota: Lobariaceae) in Colombia. Fungal Diversity 64: 205-231.

Moncada, B., Reidy, B. \& Lücking, R. 2014b. A phylogenetic revision of Hawaiian Pseudocyphellaria (lichenized Ascomycota: Lobariaceae) reveals eight new species and a high degree of inferred endemism. The Bryologist 117: 119-160.

Moncada, B., Suárez, A. \& Lücking, R. 2015. Nueve especies nuevas del género Sticta (Ascomycota liquenizados: Lobariaceae) del morfotipo fuliginosa sensu lato de Colombia. Revista de la Academia Colombiana de Ciencias Exactas, Físicas y Naturales 39: 50-66.

Mueller-Dombois, D. 1987. Forest dynamics in Hawaii. Trends in Ecology and Evolution 2: 216-220.

Nilsson, R. H., Larsson, K. H., Taylor, A. F. S., Bengtsson-Palme, J., Jeppesen, T. S., Schigel, D., Kennedy, P., Picard, K., Glöckner, F. O., Tedersoo, L. \& Saar, I. 2019. The UNITE database for molecular identification of fungi: handling dark taxa and parallel taxonomic classifications. Nucleic Acids Research 47(D1): D259-D264.

Nylander, W. 1859. Lichenes Exotici, Lichenes in regionibus exoticis quibusdam vigentes exponit synopticis enumerationibus. Annales des Sciences Naturelles 11: 205-264.

Orange, A., James, P. W. \& White, F. J. 2010. Microchemical Methods for the Identification of Lichens, 2nd Ed. London: British Lichen Society.

Pax, D. L., Price, R. A. \& Michaels, H. L. 1997. Phylogenetic position of the Hawaiian Geraniums based on rbcL sequences. American Journal of Botany 84: 72-78.

Penn, O., Privman, E., Ashkenazy, H., Landan, G., Graur, D. \& Pupko, T. 2010a. GUIDANCE: a web server for assessing alignment confidence scores. Nucleic Acids Research 38: W23-W28.

Penn, O., Privman, E., Landan, G., Graur, D. \& Pupko, T. 2010b. An alignment confidence score capturing robustness to guide-tree uncertainty. Molecular Biology and Evolution 27: 1759-1767.

Percy, D. M., Garver, A. M., Wagner, W. L., James, H. F., Cunningham, C. W., Miller, S. E. \& Fleischer, R. C. 2008. Progressive island colonization and ancient origin of Hawaiian Metrosideros (Myrtaceae). Proceedings of the Royal Society, B-Biological Sciences 275: 1479-1490.

Pišút, I. 2005. Čel'ad' Lobariaceae Chevall. (Lichenizované Huby) história, súčasnost' a trendy výskytu na Solvensku. Acta Rerum Naturalium Musei Nationalis Slovaci 51: 15-29.

Radies, D., Coxson, D., Johnson, C. \& Konwicki, K. 2009. Predicting canopy macrolichen diversity and abundance within old-growth inland temperate rainforests. Forest Ecology and Management 259: 86-97.

Ranft, H., Moncada, B., de Lange, P. J., Lumbsch, H. T. \& Lücking, R. 2018. The Sticta filix morphodeme (Ascomycota: Lobariaceae) in New Zealand, with the newly recognized species $S$. dendroides and $S$. menziesii: indicators of forest health in a threatened island biota? The Lichenologist 50: 185-210.

Rohrer, J., Costello, V., Tanino, J., Bialic-Murphy, L., Akamine, M., Sprague, J., Joe, S. \& Smith, C. W. 2016. Development of Tree Snail Protection Enclosures: From Design to Implementation. Technical Report 194. Pacific Cooperative Studies Unit, University Of Hawai’I At Mānoa, Oahu, Hawaii.

Scheidegger, C., Frey, B. \& Zoller, S. 1995. Transplantation of symbiotic propagules and thallus fragments: methods for the conservation of threatened epiphytic lichen populations. Mitteilungen der Eidgenössischen Forschungsanstalt für Wald, Schnee und Landschaft 70: 41-62.

Seaward, M. R. D. \& Aptroot, A. 2006. A preliminary checklist of lichens for the Seychelles Group. Journal of the Hattori Botanical Laboratory 100: 765-781.

Sérusiaux, E. \& Lücking, R. 2007. Gallaicolichen, a new genus of foliicolous lichen with unique diaspores. Bibliotheca Lichenologica 95: 509-516.
Simon, A., Goward, T., Di Meglio, J., Dillman, K., Spribille, T. \& Goffinet, B. 2018a. Sticta torii sp. nov., a remarkable lichen of high conservation priority from northwestern North America. Graphis Scripta 30: 105-114.

Simon, A., Goffinet, B., Magain, N. \& Sérusiaux, E. 2018b. High diversity, high insular endemism and recent origin in the lichen genus Sticta (lichenized Ascomycota, Peltigerales) in Madagascar and the Mascarenes. Molecular Phylogenetics and Evolution 122. 15-28.

Sipman, H. J. M. 2006. Diversity and biogeography of lichens in neotropical montane oak forests. Ecological Studies 185: 69-81.

Smith, C. W. 1977. Notes on Hawaiian lichens I. Obligately foliicolous species. The Bryologist 80: 342-343.

Smith, C. W. 1984. Hawaii's alectorioid lichens. Pacific Science 38: 249-252.

Smith, C. W. 1991. Lichen conservation in Hawaii. In: Galloway, D. J. (ed.), Tropical Lichens: Their Systematics, Conservation, and Ecology, 35-45. The Systematics Association Special Volume, Clarendon Press, Oxford.

Smith, C. W. 1993. Notes on Hawaiian parmelioid lichens. The Bryologist 96: 326-332.

Smith, C. W. 1995. Notes on long-distance dispersal in Hawaiian lichens: ascospore characters. Cryptogamic Botany 5: 209-213.

Smith, C. W. 2001. The lichen genus Umbilicaria in the Hawaiian Islands. Bibliotheca Lichenologica 78: 389-394.

Smith, C. W. 2002. Forest pest biological control program in Hawaii. Biological Control of Invasive Plants in Native Hawaiian Ecosystems. Technical Report 129: 91-102.

Smith, C. W. 2013. Checklist of lichens and lichenicolous fungi of Hawaii (USA). http://www.biologie.uni-hamburg.de/checklists/ oceania/usa_hawaii_1.htm

Smith, C. W., Gardner, D. E. \& Hoe, W. J. 1997. Foliicolous Hawaiian cryptogams. Abstracta Botanica 21(1): 163-167.

Stamatakis, A. 2014. RAxML version 8: a tool for phylogenetic analysis and post-analysis of large phylogenies. Bioinformatics 30: 1312-1313.

Stenroos, S. \& Smith, C. W. 1993. Notes on the amphipacific relations of Hawaiian Cladoniaceae. Tropical Bryology 8: 275-280.

Stevens, G. N. 1991. The tropical Pacific species of Usnea and Ramalina and their relationship to species in other parts of the world. In: Galloway, D. J. (ed.), Tropical Lichens: Their Systematics, Conservation, and Ecology, pp. 47-67. The Systematics Association Special Volume, Clarendon Press, Oxford.

Swinscow, T. D. V. \& Krog, H. 1988. Macrolichens of East Africa. British Museum (Natural History), London.

Tibell, L. B. 1994. Distribution patterns and dispersal strategies of Caliciales. Botanical Journal of the Linnean Society 116: 159-202.

Tuckerman, E. 1866. Enumeration of Hawaiian Plants: Lichens. Proceedings of the American Academy of Arts and Sciences 7: 223-234.

Tunison, J. T., Smith, C. W. \& Stone, C. P. 1992. Alien plant management in Hawai'i: conclusions. In: Stone, C. P, Smith, C. W. \& Tunison, J. T. (eds), Alien plant invasions in native ecosystems of Hawaii: management and research, pp. 821-833. University of Hawaii Cooperative National Park Resources Studies Unit, Honolulu.

Van den Boom, P. P., Brand, M., Ertz, D., Kalb, K., Magain, N., Masson, D., Schiefelbein, U., Sipman, H. J. M. \& Sérusiaux, E. 2011. Discovering the lichen diversity of a remote tropical island: working list of species collected on Reunion (Mascarene archipelago, Indian Ocean). Herzogia 24: 325-350.

Vondrák, J., Ríha, P., Arup, U. \& Søchting, U. 2009. The taxonomy of the Caloplaca citrina group (Teloschistaceae) in the Black Sea region, with contributions to the cryptic species concept in lichenology. The Lichenologist 41: 571-604.

Wagner, W. L. \& Funk, V. A. (eds) 1995. Hawaiian Biogeography: Evolution on a Hot Spot Archipelago. Smithsonian Institution Press, Washington DC. 
Wagner, W. L. \& Herbst, D. R. 2002. Electronic Supplement to the Manual of the Flowering Plants of Hawai ' $i$. http://rathbun.si.edu/ botany/pacificislandbiodiversity/hawaiianflora/supplement.htm

Wagner, W. L., Herbst, D. R. \& Sohmer, S. H. 1999. Manual of the Flowering Plants of Hawai'i: Revised Edition. Volume 1 and 2. University of Hawai'i Press \& Bishop Museum Press, Honolulu.

Werth, S. 2011. Biogeography and phylogeography of lichen fungi and their photobionts. In: Fontaneto, D. (ed.), Biogeography of Microscopic Organisms: Is Everything Small Everywhere?, pp. 191-208. Cambridge University Press, Cambridge.

White, T. J., Bruns, T. D., Lee, S. \& Taylor, J. 1990. Amplification and direct sequencing of fungal ribosomal RNA genes for phylogenetics. In: Innis, M. A., Gelfand, D. H., Sninsky, J. J. \& White, T. J. (eds), PCR Protocols, pp. 315-322. Academic Press, San Diego.

Widhelm, T. J., Bertoletti, F. R., Asztalos, M. J., Mercado-Díaz, J. A., Huang, J.-P., Moncada, B., Lücking, R., Magain, N., Sérusiaux, E. \& Goffinet, B. 2018. Oligocene origin and drivers of diversification in the genus Sticta (Lobariaceae, Ascomycota). Molecular Phylogenetics and Evolution 126: 58-73.

Wirth, V. 1995. Die Flechten Baden-Württembergs, Teil 1 \& 2. Ulmer, Stuttgart.

Wirth, V. 1997. Additional lichen records from Oceania 3. Trapeliopsis flexuosa. Australasian Lichenological Newsletter 40: 11
Wright, S. D., Yong, C. G., Wichman, S. R., Dawson, J. W. \& Gardner, R. C. 2001. Stepping stones to Hawaii: a trans-equatorial dispersal pathway for Metrosideros (Myrtaceae) inferred from nrDNA (ITS+ETS). Journal of Biogeography 28: 769-774.

Yoshimura, I. 1984. Taxonomic studies on Lobaria crenulata and its allies. Journal of the Hattori Botanical Laboratory 57: 97-126.

Yoshimura, I. 1998. Lobaria in Latin America: taxonomic, geographic and evolutionary aspects. In: Marcelli, M. P. \& Seaward, M. R. D. (eds), Lichenology in Latin America: History, Current Knowledge and Applications, pp. 129-134. CETESB - Companhia de Tecnologia de Saneamento Ambiental, São Paulo.

Yoshimura, I. \& Arvidsson, L. 1994. Taxonomy and chemistry of the Lobaria crenulata group in Ecuador. Acta Botanica Fennica 150: 223-333.

Zahlbruckner, A. 1903. Neue Flechten. Annales Mycologici 1: 354-361.

Zahlbruckner, A. 1925. Catalogus Lichenum Universalis. Volume 3. Borntraeger, Leipzig.

Zoller, S., Scheidegger, C. \& Sperisen, C. 1999. PCR primers for the amplification of mitochondrial small subunit ribosomal DNA of lichen-forming ascomycetes. The Lichenologist 31: 511-516.

Zotz, G., Büdel, B., Meyer, A., Zellner, H. \& Lange, O. L. 1998. In situ studies of water relations and $\mathrm{CO}_{2}$ exchange of the tropical macrolichen, Sticta tomentosa. New Phytologist 139: 525-535. 